\title{
Influence of Properties of Gas Diffusion Layers on the Performance of Polymer Electrolyte-based Unitized Reversible Fuel Cells
}

Chul Min Hwang a, Masayoshi Ishida a, Hiroshi Ito b*, Tetsuhiko Maeda b, Akihiro

Nakano b, Yasuo Hasegawa b, c, Naoto Yokoi c , Atsushi Kato d, Tetsuya Yoshida e

a Department of Engineering Mechanics and Energy, University of Tsukuba, 1-1-1

Tennoudai, Tsukuba 305-8573, Japan

b Energy Technology Research Institute, National Institute of Advanced Industrial

Science and Technology (AIST), 1-2-1 Namiki, Tsukuba 305-8564, Japan

c Tokyo Institute of Technology, 4259 Nagatsuda, Midori-Ku, Yokohama 226-8503,

Japan

d Takasago Thermal Engineering Co., Ltd., 3150 Iiyama, Atsugi 243-0213, Japan

e Daiki Ataka Engineering Co., Ltd., 11 Shintoyofuta, Kashiwa 277-8515, Japan

* Corresponding author, E-mail: ito.h@aist.go.jp,

Tel: +81-29-861-7262, Fax: +81-29-851-7523 


\begin{abstract}
Polymer electrolyte-based unitized reversible fuel cells (URFCs) combine the functionality of a fuel cell and an electrolyzer in a single device. In a URFC, titanium (Ti)-felt is used as a gas diffusion layer (GDL) of the oxygen electrode, whereas typical carbon paper is used as a GDL of the hydrogen electrode. Different samples of Ti-felt with different structural properties (porosity and fiber diameter) and PTFE content were prepared for use as GDLs of the oxygen electrode, and the relation between the properties of the GDL and the fuel cell performance was examined for both fuel cell and electrolysis operation modes. Experimental results showed that the cell with a Ti-felt GDL of $80 \mu \mathrm{m}$ fiber diameter had the highest round-trip efficiency due to excellent fuel cell operation under relatively high-humidity conditions despite degradation in performance in the electrolysis mode.
\end{abstract}

Key words: proton exchange membrane, unitized reversible fuel cell, gas diffusion layer, titanium felt, water management 


\section{Nomenclature}

i

F

$s$

$T_{\text {cell }}$

$T_{\text {fuel }}$

V

Greek symbols

$\varepsilon$

$\zeta$

$\eta$

$\phi$

Subscripts

act

conc

ELY

FC

OCV

ohm

RT

tn current density, $\mathrm{A} \mathrm{m}^{-2}$

Faraday constant, 96,485 $\mathrm{C} \mathrm{mol}^{-1}$

liquid saturation of gas diffusion layer

cell temperature, $\mathrm{K}\left({ }^{\circ} \mathrm{C}\right)$

fuel humidification temperature, $\mathrm{K}\left({ }^{\circ} \mathrm{C}\right)$

voltage, $\mathrm{V}$

porosity

ratio of mean pore diameter and bubble point diameter

overpotential , V / efficiency

fiber diameter, $\mu \mathrm{m}$

activation

concentration

electrolysis

fuel cell

open circuit voltage

ohmic

round-trip

thermo-neutral 
Abbreviation

BPD

bubble point diameter

CFP

capillary flow porometry

DMFC

direct methanol fuel cell

FRA

frequency response analyzer

GDL

gas diffusion layer

MEA

membrane electrode assembly

MIP

mercury intrusion porosimetry

MPD

mean pore diameter

MPL

microporous layer

PEM

proton exchange membrane

PEMFC

proton exchange membrane fuel cell

PTFE

polytetrafluoroethylene

URFC

unitized reversible fuel cell 


\section{Introduction}

Polymer electrolyte-based unitized reversible fuel cells (URFCs) can operate as electrolyzers to split water into hydrogen and oxygen by using electric power. When fed hydrogen and oxygen or air, the same cell/stack set-up can operate as a fuel cell to supply electric power. In actual operation, URFCs can be reversed and switched so that they can act as both an electrolyzer and a fuel cell. Due to its low self-discharge, a URFC system that includes a hydrogen storage unit is attracting attention for its role in long-term energy storage and back-up power, and can thus replace a secondary battery in some applications [1-14].

Figure 1 shows a set-up of a URFC with single-cell structure. This configuration of a URFC with a proton exchange membrane (PEM) is a commonly used "conventional" proton exchange membrane fuel cell (PEMFC), consisting of a membrane electrode assembly (MEA), gas diffusion layers (GDLs), and bipolar plates with flow channels. There are two major differences in the GDL conditions between the operations of PEMFC and URFC. The first difference is the hydration state of the GDLs. During fuel cell operation mode of a URFC, humidified gases humidify the membrane as they do in a PEMFC. However, excess liquid water in the GDL hinders gas transport, especially in the oxygen electrode (the cathode during fuel cell mode), thus inducing loss 
in mass transport. Under typical PEMFC conditions, the estimated ratio of liquid water saturation in the GDL ranges from 0.1 to 0.3 [15], which is the same as that during fuel cell mode in a URFC. In contrast, during electrolysis mode in a URFC, the GDLs are actually fully saturated by liquid water and their two main roles are electric conduction between the electrode and the bipolar plates and efficient gas transport from the electrode to the flow channels. Thus, a pre-switching gas purge to dry the GDL is needed for smooth switching from electrolysis mode to fuel cell mode during actual operation of a URFC [16]. The second difference is the potential at the oxygen electrode. For a typical PEMFC, carbon paper or carbon cloth is used as the GDL at both sides of the electrodes. However, for the oxygen electrode of a URFC, carbon material is unsuitable for not only the electrode but also for the GDL, because the potential of the oxygen electrode during electrolysis mode is so cathodic that carbon material tends to corrode. Thus, for the GDL of the oxygen electrode, we use a titanium (Ti)-felt (nonwoven fabric) in which Ti fiber is bonded and sintered without adhesives.

As mentioned before, the GDL of a conventional PEMFC plays a crucial role in water management within the cell, that is, to maintain an appropriate water balance between the conservation of membrane humidity and the discharge of produced water in the cell. A microporous layer (MPL) is commonly used in a PEMFC, and is usually 
made of a mixture of fine carbon particles and a hydrophobic agent coated on one side of a conventional GDL such as a carbon paper. At a high current density, PEMFCs with an MPL generally exhibit better performance than those without an MPL [17-23]. Although there is an ongoing argument about the role of an MPL [24-31], the hypothesis based on experimental results presented by Gostick et al. [31] is the most convincing, that is, GDL saturation at water breakthrough is drastically reduced in the presence of an MPL, while leaving a path for gas transport. However, a typical MPL made of carbon cannot be used for the oxygen electrode of a URFC (i.e., the cathode during fuel cell mode), because the potential of the oxygen electrode during electrolysis mode is so cathodic that carbon material tends to corrode.

Carbon paper is the most commonly used material for the GDL substrate of a PEMFC. Regardless if an MPL is added to the GDL, a hydrophobic agent such as PTFE is usually added to the GDL substrate to enhance the hydrophobicity of the GDL. However, when an MPL is added, the gas permeability of the MPL governs the electrode performance, and the PTFE content in the GDL substrate has no noticeable effect on fuel cell performance [18]. Although several studies [32,33] have focused on the effect of PTFE content in carbon paper without an MPL, the effect on fuel cell performance remains unclear. Gostick et al. [34,35] measured the saturation curve versus capillary 
pressure using a carbon paper substrate with or without PTFE treatment. The experimental curves indicate that untreated substrates imbibe liquid water at relatively low capillary pressure rather than treated ones. On the other hand, because carbon paper is an "off-the-shelf" commercial product (Toray or SGL), the diameter of the carbon fibers and the porosity of the GDL cannot be customized or controlled by the user.

In a PEM electrolyzer, stable electrical conductance and gas transport require a porous metal substrate as the GDL (current collector), such as sintered porous metal, expanded metal mesh, or metal felt. Grigoriev et al. [36] examined an optimum pore size of GDL from both experimental and modeling approaches from the view point of mass transport. They used a plate of sintered Ti-powder as the GDL of electrolyzer, and concluded the optimum pore size is $12-13 \mu \mathrm{m}$. On the other hand, a similar phenomenon to the gas production during electrolysis is observed at the anode of a direct methanol fuel cell (DMFC) where carbon dioxide generated at the electrode diffuses through the GDL and flows into the channel flow of methanol. Several studies were focusing on the gas evolution and diffusion though a GDL in a DMFC [37-41]. However structural properties of a GDL cannot be changed arbitrarily, because carbon paper is also used as the GDL substrate at both electrodes in a DMFC. 
Ioroi et al. [9] examined the relationship between the PTFE loading amount on Ti-felt and the URFC performance when Ti-felt is used as the GDL of a URFC. They reported that an optimal PTFE amount is needed for better performance during fuel cell mode, although the electrolysis performance degrades with increasing PTFE amount. However, in their experiments, the flow rate of supplied gas during fuel cell mode was constant and the stoichiometric ratio of gas was relatively high $\left(5.6\right.$ at $500 \mathrm{~mA} / \mathrm{cm}^{2}$ for oxygen). Song et al. [12] attempted using an MPL made of Ti particles with a carbon paper GDL in a URFC, but did not observe the expected improvement in fuel cell performance.

As in a conventional PEMFC, the GDLs of a URFC are responsible for an optimum humidification state and liquid water distribution in the catalyst layer during both the fuel cell mode and electrolysis mode. Complete understanding of the relation between liquid water transport and Ti-felt GDL characteristics is necessary to improve URFC performance.

The objective of our present work is to verify the influence of the properties of Ti-felt GDLs for liquid water and oxygen gas transport in the oxygen electrode of a URFC. First, different samples of Ti-felt with different structural properties (porosity and fiber diameter) and PTFE content were prepared for the GDL of the oxygen 
electrode. Then, polarization curves were obtained based on URFC performance tests.

Finally, based on the test results and overpotential analysis, the relation between URFC performance and water management ability of a Ti-felt GDL was verified.

\section{Experiments}

The design and configuration of the URFC with single-cell structure (Fig. 1) used here was the same as that for a PEMFC. The bipolar plate of the oxygen electrode side was $\mathrm{Ti}$, and that of the hydrogen electrode side was carbon. Both bipolar plates had a parallel flow field that had 26 channels. The MEA used here was developed through collaboration between Takasago Thermal Engineering Co. and Daiki Ataka Engineering Co. The catalytic electrodes were hot pressed to both surfaces of the membrane. Nafion 115 was used as the PEM. Iridium oxide $\left(\mathrm{IrO}_{2}\right)$ and platinum $(\mathrm{Pt})$ mixed-electrocatalyst was used for the oxygen electrode, and Pt catalyst for the hydrogen electrode. The MEA (with an active area of $27 \mathrm{~cm}^{2}$ ) and the GDLs were placed between the flow fields of both bipolar plates (Fig. 1).

Figure 2 shows micrographs of the carbon paper (Toray 090) and Ti-felt (Bekinit) used for the GDLs. Both substrates had similar structure of an unwoven fabric made of fine fibers. The carbon fibers were about $10 \mu \mathrm{m}$ in diameter. The fiber diameter 
of this Ti-felt substrate was $20 \mu \mathrm{m}$ (Fig. 2), which is the minimum diameter that we could obtain, and about double that of the carbon paper. There is no adhesive in the Ti-felt substrate, while a certain amount of adhesive is included in the carbon paper substrate. Thus the pore diameter of the Ti-felt was larger than that of the carbon paper. Various Ti-felt GDLs with different properties and PTFE content (Table I) were prepared for the oxygen electrode for the URFC performance tests. The thickness of either of the Ti-felt or carbon paper substrate was approximately $300 \mu \mathrm{m}$. In all experiments in this work, the carbon paper GDL (Toray 090) treated with 10 wt.\% PTFE emulsion was used for the hydrogen electrode side. In the U2, U3, and F2 cells, PTFE was loaded on the GDL substrate as follows. After each GDL substrate was dipped in a given PTFE emulsion (D-210C, Daikin), first it was dried at $120^{\circ} \mathrm{C}$ for 1 hour to evaporate the remaining solvent, and then sintered at $360^{\circ} \mathrm{C}$ in the vacuum condition for 1 hour to uniformly distribute the PTFE in the substrate. Figure 3 shows the amount of loaded PTFE on the substrate as a function of PTFE concentration in the emulsion. The PTFE content in the GDL can be controlled by adjusting the PTFE concentration in the emulsion, and is approximately the same in both the carbon paper and Ti-felt substrates, based on external geometry. The weight ratio of PTFE on the carbon paper GDL treated with 10 wt.\% of emulsion was 14.3 wt.\%. In this study, the 
U1 cell in Table I was considered the standard cell in which the Ti-felt GDL in the oxygen side had a fiber diameter $(\phi)$ of $20 \mu \mathrm{m}$ and a porosity $(\varepsilon)$ of 0.75 without PTFE loading. The Ti-felt GDL of the U2 and U3 cells had the same properties ( $\phi$ and $\varepsilon$ ) as the U1 cell but were treated with different PTFE concentrations in the emulsion, namely, 10 and 20 wt.\%, respectively. The Ti-felt GDL in the oxygen electrode side of the U4 and U5 cells had the same $\varepsilon$ as in the U1 cell but had different $\phi$, namely, $40 \mu \mathrm{m}$ and $80 \mu \mathrm{m}$, respectively, without PTFE loading. The Ti-felt GDL in the U6 cell had the same fiber diameter as in the U1 cell but had different porosity, 0.50. The F1 and F2 cells with the carbon paper GDL in the oxygen electrode side were used for comparison with the Ti-felt GDL. The carbon paper GDL of F2 was treated with 10 wt.\% PTFE emulsion, whereas that of F1 was not treated with PTFE.

The gas and liquid supply lines for the fuel cell mode and electrolysis mode of the URFC were separate, but were connected at the inlet and outlet of the cell at both sides of the electrodes via switching valves. Table II lists the operating conditions of the URFC during the two modes.

Fuel cell performance tests were performed using a station specifically equipped for the fuel cell mode (PEMTEST8900, Toyo), namely, with a temperature controller for the cell and a gas supply unit with mass flow meters and humidifiers. The 
cell temperature was kept constant by electric heaters on both cover-plates controlled by the station during both the fuel cell and electrolysis modes. Air was used as an oxidant during the fuel cell mode. The stoichiometric ratio of the supplied pure hydrogen and oxygen in the air was kept at 1.43 and 2.50, respectively, and the humidification temperatures of both were changed arbitrarily but were always the same for a given test. The fluid pressure in the cell was kept at atmospheric pressure during both operation modes. The temperatures of the supply lines were controlled by ribbon heaters via temperature controllers to avoid condensation of humidified gas before entering the cell. The electric load (890CL, Scribner) was controlled by the station and used in measuring the current-voltage $(i-V)$ characteristics of the fuel cell. The AC impedance of the cell was measured using a frequency response analyzer (FRA) (1255B, Solartron) and the load.

In the electrolysis mode, water was circulated by using an accumulator, pump, preheating tank, flow meter, and flow control valve. De-ionized liquid water supplied to the cell was heated to the same temperature as the cell by a preheating tank. Theoretically, water must be supplied only to the oxygen electrode side, because water molecules move to the hydrogen electrode with protons during electrolysis. In our experiments, however, water was circulated at a flow rate of $50 \mathrm{ml} / \mathrm{min}$ at both sides of 
the electrodes to prevent membrane burn-out caused by lack of water. Two-phase flow of gas and liquid was released from the exit of the cell at both electrodes, and the produced gas $\left(\mathrm{H}_{2}\right.$ and $\left.\mathrm{O}_{2}\right)$ was separated from liquid water at the respective accumulators. DC power for the electrolysis was supplied and controlled by a power supply (PAN16, Kikusui). Cell voltage was measured at each current and the flow rate of the generated hydrogen was measured using a soap-film flow meter (SF-1U, Horiba) before the hydrogen was vented.

Capillary flow porometry (CFP) and mercury intrusion porosimetry (MIP) were applied to evaluate the properties of GDL substrate. The bubble point diameter (BPD) and the mean pore diameter (MPD) of each GDL substrate (Ti-felt and carbon paper) were measured by a CFP instrument (PSM165, Yuasa-Ionics) using the bubble point technique $[40,41]$. BPD is calculated by "bubble point" pressure which is required to blow the first continuous bubbles detectable by their rise through a layer of wetting liquid covering the sample. MPD is calculated by the pressure at the intersection of one-half dry-flow line and the wet flow line. Mercury intrusion porosimetry (MIP) is a well-known method that can be applied to porous materials because mercury with its high surface tension is forced into the pores of the samples. The amount of mercury uptake as a function of pressure allows one to calculate a pore size distribution. 


\section{Analysis for overpotential of FC operation mode}

When the operating current density (i) of a fuel cell mode is higher than zero, the cell voltage deviates from the open-circuit voltage and keeps decreasing due to cell polarization represented by the overpotential. Williams et al. [44] proposed an analysis technique to evaluate six sources of polarization for a PEMFC. In our present study, we summarize three types of overpotential; activation overpotential $\left(\eta_{\mathrm{act}}\right)$, concentration overpotential $\left(\eta_{\text {conc }}\right)$, and ohmic overpotential $\left(\eta_{\text {ohm }}\right)$. Thus, the polarization curve of a fuel cell mode of URFC can be described analytically as

$$
V_{\text {cell }}=V_{\mathrm{OCV}}-\left[\eta_{\mathrm{ang}}+{ }_{\text {conc }}+{ }_{\text {ohm }}\right]
$$

where $V_{\text {cell }}$ is the cell voltage at a given $i$, and $V_{\mathrm{OCV}}$ is the open-circuit voltage.

The ohmic overpotential is determined by the ohmic resistance $\left(R_{\text {cell }}\right)$ and $i$ as follows:

$$
\eta_{\text {ohm }}=i R_{\text {cell }}
$$

Although $R_{\text {cell }}$ is associated with total resistance of proton and/or electron transport of the cell, it mainly depends on the proton conductivity through the membrane. The proton conductivity actually depends on the humidification state of the membrane. In our study, $R_{\text {cell }}$ was represented by the AC impedance of the cell measured by the FRA at $10 \mathrm{kHz}$ at each $i$. 
In terms of $\eta_{\text {act }}$, the kinetic Tafel slope can be determined from the experimentally measured $V_{\text {cell }}$ plotted against $\log i$ in the activation control portion. In our study, a range of $V$ from $10-100 \mathrm{~mA} / \mathrm{cm}^{2}$ was chosen to obtain the kinetic-controlled Tafel slope because it is low enough that $\eta_{\text {conc }}$ can be assumed negligible. Here, $\eta_{\text {act }}$ can be expressed in terms of the Tafel slope and the exchange current density $\left(i_{0}\right)$ as follows;

$$
\eta_{\mathrm{act}} \approx \frac{R T}{\alpha n F} \ln \left(\frac{i}{i_{0}}\right)=\left[\frac{2.3 R T}{\alpha n F}\right] \log \left(\frac{i}{i_{0}}\right)
$$

where $\alpha$ denotes the transfer coefficient, and $[2.3 R T / \alpha F]$ is the Tafel slope. Here, $i_{0}$ and

Tafel slope were obtained using an iteration plotting method from the polarization curve in the range of $10-100 \mathrm{~mA} / \mathrm{cm}^{2}$.

Finally, $\eta_{\text {conc }}$ at each $i$ was determined by substituting $V_{\mathrm{OCV}}, \eta_{\text {act }}$ and $\eta_{\text {ohm }}$ into Eq, 1. Theoretically, $\eta_{\text {conc }}$ is associated with the gas transport resistance through the GDL and the ionomer film at not only the oxygen electrode but also the hydrogen electrode. However, $\eta_{\text {conc }}$ at the hydrogen electrode (anode of an FC cell) is much smaller than that at the oxygen electrode and can therefore be considered negligible.

\section{Results and discussion}

The current-voltage $(i-V)$ characteristics for both operation modes of a URFC were evaluated in this study by using a single cell with oxygen-side GDLs whose 
substrates were either (1) Ti-felt that had different fiber diameter $\phi(20,40$, or $80 \mu m)$, porosity $\varepsilon(0.75$ or 0.50$)$, and with and without treatment with PTFE emulsion, or (2) carbon paper that had $\phi=10 \mu \mathrm{m}, \varepsilon=0.78$, and with or without treatment with 10 wt\%.PTFE emulsion.

\subsection{Electrolysis performance}

During the electrolysis mode, because carbon paper cannot be used as the GDL of the oxygen electrode side, only cells with Ti-felt GDL for the oxygen side (U1-U6 cells in Table I) were used for the electrolysis performance test. Carbon paper GDL treated with 10 wt.\% PTFE emulsion was used for the hydrogen electrode side in this performance test. Figure 5A shows the effect of PTFE content and porosity on the $i-V$ characteristics during the electrolysis mode by plotting the $i-V$ characteristics for the U1, $\mathrm{U} 2$, U3, and U6 cells. The mean pore diameter (MPD) of the Ti-felt used in U1 was about double that used in U6 (see Table 1), and the PTFE loading on the GDL substrate (U2) caused the slight decrease in MPD and the enhancement in hydrophobicity of the porous media. However, no noticeable difference was detected in the performance in these 4 cells (Fig. 5A). Figure 5B shows the effect of $\phi$ on the $i-V$ characteristics during the electrolysis mode. In this figure, the $i-V$ characteristics of $U 1$ were re-plotted and 
compared to those of U4 and U5, which differed in $\phi$ but were not treated with PTFE. In this comparison, the MPD of the Ti-felt substrate significantly increased with increasing $\phi$ from $45 \mu \mathrm{m}$ (in U1) to $207 \mu \mathrm{m}$ (in U5). The larger MPD was expected to enhance the transport of water supply to the electrode and reduce $\eta_{\text {conc }}$ at high $i$ (> 500 $\left.\mathrm{mA} / \mathrm{cm}^{2}\right)$. However, the $i-V$ curves for $\mathrm{U} 1(\phi=20 \mu \mathrm{m})$ reveals better performance for U1 than for $\mathrm{U} 4(\phi=40 \mu \mathrm{m})$ or $\mathrm{U} 5(\phi=80 \mu \mathrm{m})$ even in this high $i$ region, and the difference in $V$ between $\mathrm{U} 1$ and $\mathrm{U} 4 / \mathrm{U} 5$ is about $30 \mathrm{mV}$ at $i=0.93 \mathrm{~A} / \mathrm{cm}^{2}$, whereas the difference in $V$ between $\mathrm{U} 4$ and $\mathrm{U} 5$ is rather small $(<10 \mathrm{mV})$ at $i=1.0 \mathrm{~A} / \mathrm{cm}^{2}$. In the experimental results for the fuel cell mode discussed in the following section (4.2), there was no significant difference in cell impedance between U1 and U4/U5 at the same humidification condition (see Fig. 10). Impedance test result indicates that the difference in electrolysis performance was not caused by the difference in electrical conductance (ohmic overpotential $\eta_{\mathrm{ohm}}$ ) in the cell.

Figure 6 shows the measured pore size distribution for the Ti-felt substrates used here (U1, U5, and U6). The pore diameters corresponding to the peaks in the differential volume measured using a mercury intrusion porosimeter (MIP) agree well with the MPD measured using a capillary flow porometry (CFP) at each respective substrate as listed in Table I. Both the MIP and CFP results show that the pore 
diameter of Ti-felt in U5 was significantly larger than that in U1 due to large $\phi$. When the sum of the shear force of the flow of liquid water and the buoyancy on a bubble

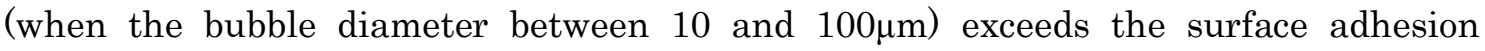
between a bubble and the electrode surface, the bubble detaches from the electrode surface $[45,46]$. The detached bubbles grow by coalescence during diffusion through the GDL, and finally flow into the channel flow. In a previous experimental study using a PEM electrolyzer [47], we reported that the flow regime of circulating water in the channel affects the electrolysis performance. When the two-phase flow of the circulating water at the oxygen electrode is either slug or annular, mass transport of water for the anode reaction is degraded and the concentration overvoltage increases at higher $i$ (> $500 \mathrm{~mA} / \mathrm{cm}^{2}$ ). A large pore diameter of a GDL substrate generates relatively large bubbles [48]. The bubble point diameters (BPD) of the Ti-felt used in U4 and U5 (Table I) were about 180 and $510 \mu \mathrm{m}$, respectively. Because the GDLs used in our study had a large pore diameter $(>100 \mu \mathrm{m})$ that could generate large bubbles and because the flow velocity of liquid was relatively small $(\sim 0.03 \mathrm{~m} / \mathrm{s})$ at the operating conditions for the electrolysis mode, bubble growth through the GDL must be significant compared to that through a GDL of small pore diameter $(<50 \mu \mathrm{m})$, and thus comparably large bubbles flow into the channel. According to the literature on two-phase flow $[49,50]$, the injected 
bubble size strongly affects the transition from bubbly to slug flow. At slug flow, the bubbles grow by coalescence and, ultimately, they become of the same order of diameter as the channel and must hinder the supply of reactant water to the electrode surface at a certain degree. Consequently, the performance loss of electrolysis is caused by the rising concentration overvoltage from this insufficient water supply. The optimum pore size of the GDL in PEM electrolyzer obtained by Grigoriev et al. [36] is rather small $(12-13 \mu \mathrm{m})$. Although we could not obtain the optimum pore size of the GDL from the present experimental results, there are no difference of the electrolysis performance in the specific region of pore size $(23-56 \mu \mathrm{m})$.

In these experiments, hydrogen production rate was measured using a soap-film meter. Although the hydrogen production rate was too small to be measured precisely when $i<200 \mathrm{~mA} \mathrm{~cm}^{-2}$, the Faraday efficiency was higher than $99.5 \%$ regardless of the type of Ti-felt GDL when $i>200 \mathrm{~mA} \mathrm{~cm}^{-2}$.

\subsection{Effect of humidification temperature on fuel cell performance}

Figure 7 shows the $i-V$ characteristics of $U 1$ during the fuel cell mode at various

humidification temperatures of the gases $\left(T_{\text {fuel }}\right)$ when the cell temperature $\left(T_{\text {cell }}\right)$ was $80^{\circ} \mathrm{C}$. The $T_{\text {fuel }}$ was the same for both hydrogen and air (between 60 to $80^{\circ} \mathrm{C}$ ) and 
controlled by a bubble humidifier. The curve for $T_{\text {fuel }}=80^{\circ} \mathrm{C}$ at $i=0.1 \sim 0.2 \mathrm{~A} / \mathrm{cm}^{2}$ and those for $T_{\text {fuel }}=60^{\circ} \mathrm{C}$ and $T_{\text {fuel }}=65^{\circ} \mathrm{C}$ at $i=0.3 \sim 0.45 \mathrm{~A} / \mathrm{cm}^{2}$ show a rapid decrease in $V$. In contrast, the curves for $T_{\text {fuel }}=70^{\circ} \mathrm{C}$ and $T_{\text {fuel }}=75^{\circ} \mathrm{C}$ do not show such a rapid decrease, but rather a relatively good performance (as evidenced by a steady decrease) until a high $i$. Figure 8 shows the three different overpotentials $\left(\eta_{\text {act }}, \eta_{\text {conc }}\right.$, and $\left.\eta_{\text {ohm }}\right)$ obtained from $i-V$ curves of the U1 cell using the overpotential analysis method described in Section 3. The decrease in fuel cell performance at $T_{\text {fuel }}=80^{\circ} \mathrm{C}$ was caused by a rapid increase in $\eta_{\text {conc }}$ (Fig. 8B). This increase in $\eta_{\text {conc }}$ was caused by a common phenomenon of flooding in GDL due to both the high humidity and produced water that blocks the fuel distribution in pores of the oxygen-side GDL. When $T_{\text {fuel }}=60$ and $65^{\circ} \mathrm{C}$, the $\eta_{\text {ohm }}$ was relatively high (Fig. $8 \mathrm{C}$ ) due to an increase in cell resistance caused by insufficient water supply to the membrane. Although $\eta_{\text {act }}$ tended to increase with a decrease in $T_{\text {fuel }}$, the difference of $\eta_{\text {act }}$ was relatively small (Fig. 8A). Comparison of the $i-V$ (Fig. 7) and overpotential characteristics (Fig. 8) at $T_{\text {fuel }}=70$ and $75^{\circ} \mathrm{C}$ reveals that the lower $\eta_{\text {conc }}$ at $T_{\text {fuel }}=70^{\circ} \mathrm{C}$ yielded better $i-V$ characteristics than that at $T_{\text {fuel }}=75^{\circ} \mathrm{C}$. In contrast, $\eta_{\text {ohm }}$ at $T_{\text {fuel }}=75^{\circ} \mathrm{C}$ was less than that at $T_{\text {fuel }}=70^{\circ} \mathrm{C}$ (Fig. $8 \mathrm{~B}, \mathrm{C}$ ). This reversal in $\eta_{\text {conc }}$ and $\eta_{\text {ohm }}$ at $T_{\text {fuel }}=70$ and $75^{\circ} \mathrm{C}$ indicates a optimum critical point of "dry" and "wet" conditions during the fuel cell mode, and thus, an optimum $T_{\text {fuel }}$ in the range from 70 and $75^{\circ} \mathrm{C}$. 
Figure 9 shows $i$ and $\eta_{\text {act }}$ for cells with different GDLs of the oxygen electrode

(Table I). When $T_{\text {fuel }}$ was 70 or $75^{\circ} \mathrm{C}$, the difference in $\eta_{\text {act }}$ was small among these cells; the maximum difference was only $15 \mathrm{mV}$ at $i=650 \mathrm{~mA} / \mathrm{cm}^{2}$. Figure 10 shows $i$ and $\eta_{\text {ohm }}$ for the same cells in Fig. 9. The difference in $\eta_{\text {ohm }}$ was small among these cells for either $T_{\text {fuel }}$ of 70 and $75^{\circ} \mathrm{C}$, including the cells using the carbon-paper GDL for the oxygen electrode (F1 and F2). The cell impedance was almost constant at the entire range of current densities, and was $0.148 \Omega \mathrm{cm}^{2}$ and $0.098 \Omega \mathrm{cm}^{2}$ at 70 and $75^{\circ} \mathrm{C}$ of $T_{\text {fuel }}$, respectively. The consistency of the cell impedance at each $T_{\text {fuel }}$ indicates that the $\eta_{\text {ohm }}$ is an index of hydration state of the membrane and strongly depends on $T_{\text {fuel, }}$ whereas the electrical resistance of the cell is insignificant. Because $\eta_{\text {act }}$ and $\eta_{\text {ohm }}$ were the same at both temperatures regardless of the properties of the oxygen electrode GDL, in order to verify the relationship between the properties of the Ti-felt GDL and the fuel cell performance, we focused only on the $i-V$ characteristics and $\eta_{\text {conc }}$ at $T_{\text {fuel }}=70$ and $75^{\circ} \mathrm{C}$ in the following analysis.

\subsection{Effect of PTFE content in GDL on fuel cell performance}

The effect of PTFE content in the GDL substrate of the oxygen electrode on fuel cell performance was evaluated here by analyzing the $i-V$ characteristics and $\eta_{\text {conc. }}$ 
Figure 11 shows the $i-V$ characteristics at $T_{\text {fuel }}=70$ and $75^{\circ} \mathrm{C}$ for the U1, U2, and U3 cells fuel cells (Ti-felt GDL treated with 0, 10, or 20 wt.\% PTFE emulsion, respectively), and for the F1 cell (carbon paper GDL without PTFE treatment). In contrast to the U1, U2, and U3 cells, the F1 cell could only be operated as a fuel cell of URFC because it contained carbon paper GDL in the oxygen side. Figure 11 shows that higher PTFE content in the GDL caused a noticeable degradation in cell performance at $T_{\text {fuel }}=75{ }^{\circ} \mathrm{C}$. Degradation was also observed at $T_{\text {fuel }}=70^{\circ} \mathrm{C}$, although it was relatively small. Figure 12 compares the $\eta_{\text {conc }}$ calculated from the $i-V$ curves shown in Fig. 11. No significant difference in $\eta_{\text {act }}$ and $\eta_{\text {ohm }}$ at the respective $T_{\text {fuel }}$ (Figs. 9 and Fig. 10, respectively) indicates that the drastic drop in $V$ was mainly due to the increase in $\eta_{\text {conc. }}$. Moreover, the hydration state of the electrode (i.e., catalyst layer) can be assumed nearly equal to that of the membrane indicated by $\eta_{\text {ohm }}$, the oxygen transport resistance through the ionomer film at the electrode must be almost the same at a given $T_{\text {fuel. }}$ Thus, the diffrence in $\eta_{\text {conc }}$ at the same $T_{\text {fuel }}$ can be attributed to the difference in GDL properties. Generally, $\eta_{\text {conc }}$ at $T_{\text {fuel }}=75^{\circ} \mathrm{C}$ was larger than that at $T_{\text {fuel }}=70{ }^{\circ} \mathrm{C}$, because the cell was relatively "wet" at $T_{\text {fuel }}=75{ }^{\circ} \mathrm{C}$, and the excess water hindered the mass transport of oxygen gas to the electrode surface. In addition, $\eta_{\text {conc }}$ was higher at higher PTFE content in the Ti-felt GDL at the oxygen electrode, particularly at the wet condition when $T_{\text {fuel }}=75{ }^{\circ} \mathrm{C}$ 
compared with that at the dry condition when $T_{\text {fuel }}=70^{\circ} \mathrm{C}$.

Figure 13 shows effect of PTFE content on the fuel cell performance represented as the $i-V$ characteristics at $T_{\text {fuel }}=70$ and $75^{\circ} \mathrm{C}$ for the $\mathrm{F} 1$ and $\mathrm{F} 2$ cells (carbon-paper GDL without and with treatment of 10 wt.\% PTFE emulsion). Similiar to the results for Ti-felt (Fig. 11), the negative effect of PTFE loading on the carbon-paper GDL is clearly evident at $T_{\text {fuel }}=75^{\circ} \mathrm{C}$.

The higher PTFE content was expected to enhance both the hydrophbicity of porous network and the discharge of liquid water from the electrode surface to the channel, and thus improve the fuel cell performance at high $i\left(>400 \mathrm{~mA} / \mathrm{cm}^{2}\right)$. However, our result showed an opposite trend. Figure 14 shows the liquid saturation (s) capillary pressure $\left(P_{\mathrm{c}}\right)$ curves of the PTFE treated and untreated GDL of Toray 090 (without MPL) measured by Gostick et al. [34]. The negative capillary pressure during water withdrawal from the PTFE treated substrate was smaller than that from the untreated one, whereas the positive capillary pressure for water injection at PTFE treated substrate was larger than that at the untreated one. It reveals that the loading of hydrophobic agents gives to GDL substrate the effect of disturbing the water injection and the effect of promoting the water removal. In addition, note that the difference of $P_{\mathrm{c}}$ during injection is relatively large at "wet" condition in the saturation (s) range over 0.2. 
Based on literature data $[15,51]$, when we assume that the liquid saturation in the GDL

substrate $(s)$ lies in the range of $0.2^{-}-0.3$ at the wet condition of $T_{\text {fuel }}=75^{\circ} \mathrm{C}$ and in the range of $0.1-0.15$ at the dry condition of $T_{\text {fuel }}=70^{\circ} \mathrm{C}$, the relation of $P_{\mathrm{c}}$ during injection and fuel cell performance can be deduced as follows. In the "wet" condition, PTFE treated GDL is much higher amount of work required for forcing water into the GDL from the catalyst layer than untreated one. Thus, the amount of residual water must be increased easily at the interface of the catalyst layer and the GDL and cause the degradation of fuel cell performance at higher current density $\left(>400 \mathrm{mAcm}^{-2}\right)$. On the other hand, small gap of capillary pressure for water injection in "dry" condition corresponds to the slight difference of fuel cell performance at $T_{\text {fuel }}=70^{\circ} \mathrm{C}$. Consequently, the negative effect of PTFE loading observed here could be explained by the effect of disturbing of water injection.

Typically, a PEMFC uses a GDL coated with a microporous layer (MPL). When an MPL is added to the GDL, the gas permeability of MPL, is related to its morphology, governs the electrode performance, and the PTFE content in the macroporous layer (GDL substrate) does not signficantly affect the fuel cell performance[18, 30]. Several studies have focused on the effect of PTFE loading on the GDL substrate without an MPL [32,33]. Based on experimental results for a PEMFC using carbon-paper GDL 
without an MPL, Park et al. [32] reported that a high PTFE content in the GDL hinders the discharge of liquid-phase water from the electrode to the flow channels. In our present study, an MPL was not added to the Ti-felt GDL, and thus the negative effect of PTFE loading on the Ti-felt GDL that we observed is consistent with the results reported by Park et al. for the carbon paper GDL of an PEMFC.

\subsection{Effect of fiber diameter of GDL on fuel cell performance}

The effect of fiber diameter $\phi$ of Ti-felt GDL on fuel cell performance was also evaluated based on $i-V$ characteristics and $\eta_{\text {conc }}$ analysis. Figure 15 shows polarization behavior for the U1, U4, and U5 cells, where Ti-felt GDL with $\phi=20,40$, and $80 \mu \mathrm{m}$, respectively, was used for the oxygen electrode. (Each Ti-felt GDL had a porosity of 0.75 and was not treated with PTFE.) At $T_{\text {fuel }}=70^{\circ} \mathrm{C}$, the $i-V$ characteristics for the U1, U4, and U5 cells showed no significant difference. At $T_{\text {fuel }}=75^{\circ} \mathrm{C}$, the fuel cell performance improved with increasing $\phi$, with U5 $(\phi=80 \mu \mathrm{m})$ showing the highest and most stable fuel cell performance. Figure 16 shows $\eta_{\text {conc }}$ for $\mathrm{U} 1, \mathrm{U} 4$, and $\mathrm{U} 5$ at $T_{\text {fuel }}=75^{\circ} \mathrm{C}$. The $\eta_{\text {conc }}$ for U5 was relatively low and stable up to a high $i\left(>400 \mathrm{~mA} / \mathrm{cm}^{2}\right)$. The better $i-V$ characteristics for U5 were mainly due to a lower $\eta_{\text {conc. }}$ 


\subsection{Effect of GDL porosity on fuel cell performance}

The effect of porosity $\varepsilon$ of Ti-felt GDL on fuel cell performance was evaluated based on the $i-V$ characteristics and $\eta_{\text {conc }}$ analysis. Figure 17 shows the polarization behavior for the U1 and U6 cells, in which Ti-felt GDLs with $\varepsilon=0.75$ and 0.50 , respectively, were used for the oxygen electrode. (Each Ti-felt GDL had the same $\phi=$ $20 \mu \mathrm{m}$ and was not treated with PTFE.) At $T_{\text {fuel }}=70^{\circ} \mathrm{C}$, the fuel cell performances of U1 and U6 were almost the same. At $T_{\text {fuel }}=75^{\circ} \mathrm{C}$, however, a lower $\varepsilon$ of Ti-felt GDL (U6, $\left.\varepsilon=0.50\right)$ yielded better performance compared to a higher $\varepsilon(U 1, \varepsilon=0.75)$. Figure 18 shows $\eta_{\text {conc }}$ for U1 and U6 at $T_{\text {fuel }}=75^{\circ} \mathrm{C}$. Similar to the trend observed for $\phi$ (Sec. 4.4), the better performance represented by the $i-V$ characteristics for $\mathrm{U} 6$ was mainly due to a lower $\eta_{\text {conc, }}$ that is, the cell with a GDL of lower $\varepsilon$ showed a lower and less stable $\eta_{\text {conc }}$ and exhibited better performance during fuel cell mode up to a high $i\left(>400 \mathrm{~mA} / \mathrm{cm}^{2}\right)$ at wet conditions at $T_{\text {fuel }}=75^{\circ} \mathrm{C}$.

\subsection{Relation between Ti-felt properties and fuel cell performance}

As discussed in Sections 4.4 and 4.5, during fuel cell mode of an URFC at wet conditions at $T_{\text {fuel }}=75^{\circ} \mathrm{C}$, the cell equipped the Ti-felt GDL with larger $\phi(\mathrm{U} 5, \phi=80 \mu \mathrm{m})$ or lower $\varepsilon(\mathrm{U} 6, \varepsilon=0.50)$ shows better performance compared to the standard cell of U1 
$(\phi=20 \mu \mathrm{m}$ and $\varepsilon=0.75)$. The lower $\eta_{\text {conc }}$ of U5 and U6 (Figs. 16 and 18) apparently

enhances the liquid water discharge in the high $i$ at wet conditions. The Ti-felt GDL with larger $\phi$ of U5 has larger BPD and MPD than that of the standard cell of U1 (Table I). However, pore size cannot be correlated directly with the performance, because lower $\varepsilon$ substrate of U6 has lower BPD and MPD than the standard cell of U1. Note that both of GDL substrates in U5 and U6 have relatively higher ratio of BPD/MPD (५) (2.5 and 1.8) than that in $\mathrm{U} 1(1.26)$, indicating a relatively broad distribution of pore size. This can be confirmed by the pore-size distribution obtained using the MIP as shown in Fig. 6. In particular, the Ti-felt GDL in U6 showed a broad peak around $60 \sim 100 \mu \mathrm{m}$ in addition to the main peak at around $25 \mu \mathrm{m}$, and the GDL in U5 also showed significantly

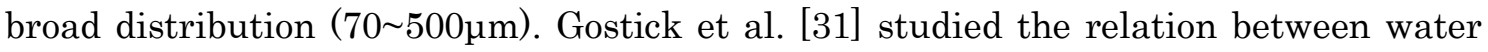
saturation in GDL and capillary pressure. They reported that the GDL saturation at water breakthrough is drastically reduced in the presence of a MPL, and, due to a crack or hole in the MPL, liquid water diffuses through a limited part of the GDL, leaving the dry path for gas transport. Thus, the large pores in the Ti-felt GDL of U5 and U6 possibly have a similar effect as the small holes in MPL, that is, liquid water preferentially moves through the larger pore sites and a specific ratio of small pore sites is inaccessible to water and kept dry and suitable for the gas transport path (Fig. 19B). 
When the GDL substrate has relatively uniform distribution as the case of U1, water percolation uniformly occurs over the entire pore network, when gas transport to the electrode is significantly hindered by the percolation (Fig. 19A). Consequently, it can be noted that the GDL substrates are characterized by the pore size distribution.

\subsection{Round -trip efficiency of URFC}

The overall performance of a URFC during the electrolysis mode and fuel cell

mode was evaluated here based on the round-trip efficiency $\left(\eta_{\mathrm{RT}}\right)$ for fuel cells with Ti-felt GDL with different $\phi$ and $\varepsilon$ used as the oxygen electrode. Figure 20 shows the $i$ and $\eta_{\mathrm{RT}}$ for U1, U5, and U6 (as discussed in Sections 4.4 and 4.5). The $\eta_{\mathrm{RT}}$ discussed here was calculated from the efficiency of cell voltage during electrolysis $\left(\eta_{\mathrm{ELY}}\right)$ and fuel cell $\left(\eta_{\mathrm{FC}}\right)$ at each $i$ as follows;

$$
\eta_{\mathrm{RT}}(i)=\eta_{\mathrm{ELY}}(i) \times \eta_{\mathrm{FC}}(i)=\frac{V_{\mathrm{FC}}(i)}{V_{\mathrm{ELY}}(i)}
$$

where $V_{\mathrm{ELY}}$ and $V_{\mathrm{FC}}$ are the cell voltage at each $i$ during electrolysis mode and fuel cell mode, respectively, and $\eta_{\mathrm{ELY}}$ and $\eta_{\mathrm{FC}}$ are defined in terms of the thermo-neutral voltage $\left(V_{\mathrm{tn}}\right)$ as follows:

$$
\left.\begin{array}{c}
\eta_{\mathrm{ELY}}(i)=\frac{V_{\mathrm{tn}}}{V_{\mathrm{ELY}}(i)} \\
\eta_{\mathrm{FC}}(i)=\frac{V_{\mathrm{FC}}(i)}{V_{\mathrm{tn}}}
\end{array}\right\}
$$


where $V_{\text {tn }}=1.481 \mathrm{~V}$. When $T_{\text {fuel }}=70^{\circ} \mathrm{C}$, because the cell operation condition is relatively dry and the properties of GDL such as $\phi$ and $\varepsilon$ do not significantly affect either $\eta_{\text {conc }}$ or the $i-V$ performance during fuel cell mode, $\eta_{\mathrm{RT}}$ does not significantly differ among the three fuel cells (U1, U5, and $\mathrm{U} 6)$. When $T_{\text {fuel }}=75^{\circ} \mathrm{C}$, however, $\mathrm{U} 5$, which showed the lowest $\eta_{\text {conc }}$ during the fuel cell mode, exhibited the highest $\eta_{\mathrm{RT}}$ despite a loss of about $30 \mathrm{mV}$ in the electrolysis mode (Sec. 4.1). The $\eta_{\mathrm{RT}}$ for U6 was higher than that for U1 but lower than that for $\mathrm{U} 5$ at high $i\left(>400 \mathrm{~mA} / \mathrm{cm}^{2}\right)$. The $\eta_{\mathrm{RT}}$ of $\mathrm{U} 1, \mathrm{U} 5$, and $\mathrm{U} 6$ at $i=740 \mathrm{~mA} / \mathrm{cm}^{2}$ was 28 , 34 , and $33 \%$, respectively, when $T_{\text {fuel }}=75^{\circ} \mathrm{C}$, and the $\eta_{\mathrm{RT}}$ of $\mathrm{U} 5$ when $T_{\text {fuel }}=75^{\circ} \mathrm{C}$ was the highest among all cells and conditions, including when $T_{\text {fuel }}=70^{\circ} \mathrm{C}$.

\section{Conclusions}

In this study, the effect of the properties of a Ti-felt GDLs on the liquid water and oxygen gas transport in the oxygen electrode of a URFC were evaluated using Ti-felts of different structural properties (porosity and fiber diameter) and PTFE content. The cell performances for both the fuel cell and electrolysis operating modes were evaluated based on the $i-V$ characteristics and the analysis of overpotentials. Based on our results, conclusions about relation between the properties of Ti-felt GDLs and the cell performance are as follows: 


\section{$\underline{U R F C}$ in electrolysis mode}

- When the fiber diameter of the Ti-felt GDL of the oxygen electrode is as small as 20 $\mu \mathrm{m}$, cell performance is not noticeably affected by a change in either the PTFE content in the GDL or porosity.

- When the fiber diameter of the Ti-felt GDL of the oxygen electrode is large as 40$80 \mu \mathrm{m}$, the cell performance is degraded at a high current density compared to a standard cell that has Ti-felt with a fiber diameter of $20 \mu \mathrm{m}$.

\section{$\underline{U R F C}$ in fuel cell mode}

- The ohmic overpotential depends only on the humidification temperature (relative humidity) of gas regardless of the properties of the GDL substrate. Thus, the cell performance at each respective humidification temperature is mainly determined by the concentration overpotential.

- When the humidification temperature $\left(T_{\text {fuel }}\right)$ is relatively low at $70^{\circ} \mathrm{C}$ and the operation condition is dry during fuel cell mode, the properties of GDL do not significantly affect either the concentration overpotential or $i-V$ characteristics.

- When the $T_{\text {fuel }}$ is relatively high at $75^{\circ} \mathrm{C}$ and the operation condition is wet, PTFE treatment for the oxygen-electrode GDL brings negative effect to the mass transport of liquid and gas. On the other hand, Ti-felts with larger fiber diameter or 
lower porosity are excellent, because the ununiformity of the pore size distribution of these substrates must cause positive effect for the mass transport.

\section{Round-trip efficiency of a URFC}

- When the cell temperature is $80^{\circ} \mathrm{C}$ for both the fuel cell and electrolysis modes, the cell with Ti-felt GDL of large fiber diameter $(80 \mu \mathrm{m})$ has the highest round-trip efficiency due to excellent fuel cell operation under high-humidity conditions $\left(T_{\text {fuel }}\right.$ $=75^{\circ} \mathrm{C}$ ) despite degradation in performance in the electrolysis mode. 


\section{References}

[1] R. Baldwin, M. Pham, A. Leonida, J. McElroy, T. Nalette, Hydrogen-oxygen proton-exchange membrane fuel cells and electrolyzers, J. Power Sources 29 (1990) 399-412.

[2] K. Bolwin, Application of regenerative fuel cells for space energy storage: a comparison to battery systems, J. Power Sources 40 (1992) 307-321.

[3] L. L. Swette, A. B. LaConti, S. A. McCatty, Proton-exchange membrane regenerative fuel cells, J. Power Sources 47 (1994) 343-351.

[4] F. Mitlitsky, B. Myers, A. H. Weisberg, Regenerative fuel cell systems, Energy Fuels $12(1998)$ 56-71.

[5] S. Zhigang, Y. Baolian, H. Ming, Bifunctional electrodes, with thin catalyst layer for 'unitized7 proton exchange membrane regenerative fuel cell, J. Power Sources 79 (1999) 82-85.

[6] W. Smith, The role of fuel cells in energy storage, J. Power Sources 86 (2000) 74-83.

[7] T. Ioroi, N. Kitazawa, K. Yasuda, Y. Yamamoto, H. Takenaka, Iridium oxide/platinum electrocatalyst for unitized regenerative fuel cells, J. Electrochem. Soc. 147 (2000) 2018-2022.

[8] T. Ioroi, K. Yasuda, Z. Siroma, N. Fujiwara, Y. Miyazaki, Thin film electrocatalyst layer for unitized regenerative polymer electrolyte fuel cells, J. Power Sources 112 (2002) 583-587.

[9] T. Ioroi, T. Oku, K. Yasuda, N. Kumagai, Y. Miyazaki, Influence of PTFE coating on gas diffusion backing for unitized regenerative polymer electrolyte fuel cells, J. 
Power Sources 124 (2003) 385-389.

[10] S. D. Yim, G. G. Park, Y. J. Sohn, W. Y. Lee, Y. G. Yoon, T. H. Yang, S. Um, S. P. Yu, C. S. Kim, Optimization of PtIr electrocatalyst for PEM URFC. Int. J. Hydrog. Energy 30 (2005) 1345-1350.

[11] U. Wittstadt, E. Wagner, T. Jungmann, Membrane electrode assemblies for unitized regenerative polymer electrolyte fuel cells, J. Power Sources 145 (2005) $555-562$.

[12] S. Song, H. Zhang, X. Ma, Z. G. Shao, Y. Zhang, B. Yi, Bifunctional oxygen electrode with corrosion-resistive gas diffusion layer for unitized regenerative fuel cell, Electrochem. Commun. 8 (2006) 399-405.

[13] H. Y. Jung, S. Y. Huang, P. Ganesan, B. N. Popov, Performance of gold-coated titanium bipolar plates in unitized regenerative fuel cell operation, J. Power Sources 194 (2009) 972-975.

[14] A. Kato, M. Masuda, A. Takahashi, T. Ioroi, M. Yamaki, H. Ito, Durability investigation of a PEM-type unitized reversible cell, ECS Transactions 25 (2009) $1271-1278$.

[15] P. K. Sinha, C. Y. Wang, Gas purge in polymer electrolyte fuel cell, J. Electrochem. Soc. 154 (2007) B1158-B1166.

[16] H. Ito, T. Maeda, A. Kato, T. Yoshida, Ø. Ulleberg, Gas purge for switching from electrolysis to fuel cell operation in polymer electrolyte unitized reversible fuel cell, J. Electrochem. Soc. 157 (2010) B1072-B1080.

[17] Z. Qi, A. Kaufman, Improvement of water management by a microporous sublayer for PEM fuel cells, J. Power Sources 109 (2002) 38-46.

[18] G. Lin, T. V. Nguyen, Effect of thickness and hydrophobic polymer content of the 
gas diffusion layer on electrode flooding level in a PEMFC, J. Electrochem. Soc. 152 (2005) A1942-A1948.

[19] J. Yu, M. N. Islam, T. Matsuura, M. Tamano, Y. Hayashi, M. Hori, Improving the performance of a PEMFC with Ketjenblack EC-600JD carbon black as the material of the microporous layer, Electrochem. Solid State Lett. 8 (2005) A320-A323.

[20] A. Z. Weber, J. Newman, Effects of microporous layers in polymer electrolyte fuel cells, J. Electrochem. Soc. 152 (2005) A677-A688.

[21] X. L. Wang, H. M. Zhang, J. L. Zhang, H. F. Xu, Z. Q. Tian, J. Chen, H. X. Zhong, Y. M. Liang, B. L. Yi, Micro-porous layer with composite carbon black for PEM fuel cells, Electochim. Acta 51 (2006) 4909-4915.

[22] S. Park, J. W. Lee, B. N. Popov, Effect of carbon loading in microporous layer on PEM fuel cell performance, J. Power Sources 163 (2006) 357-363.

[23] S. Park, J. W. Lee, B. N. Popov, Effect of PTFE content in microporous layer on water management in PEM fuel cells, J. Power Sources 177 (2008) 457-463.

[24] H. K. Atiyeh, K. Karan, B. Peppley, A. Phoenix, E. Halliop, J. Pharoah, Experimental investigation of the role of a microporous layer on the water transport and performance of a PEM fuel cell, J. Power Sources 170 (2007) $111-121$

[25] K. Karan, H. Atiyeh, A. Phoenix, E. Halliop, J. Pharoah, B. Peppley, An experimental investigation of water transport in PEMFCs: The role of microporous layers, Electrochem. Solid State Lett. 10 (2007) B34-B38.

[26] J. Chen, H. Xu, H. Zhang, B. Yi, Facilitating mass transport in gas diffusion layer of PEMFC by fabricating micro-porous layer with dry layer preparation, J. Power 
Sources $182(2008)$ 531-539.

[27] R. P. Ramasamy, E. C. Kumbur, M. M. Mench, W. Liu, Investigation of macro- and micro-porous layer interaction in polymer electrolyte fuel cells, Int. J. Hydrog. Energy 33 (2008) 3351-3367.

[28] J. H. Nam, K. J. Lee, G. S. Hwang, C. J. Kim, M. Kaviany, Microporous layer for water morphology control in PEMFC, Int. J. Heat Mass Transfer 52 (2009) 2779-2791.

[29] H. Nakajima, T. Konomi, T. Kitahara, Direct water balance analysis on a polymer electrolyte fuel cell (PEFC): Effects of hydrophobic treatment and micro-porous layer addition to the gas diffusion layer of a PEFC on its performance during a simulated start-up operation, J. Power Sources 171 (2007) 457-463.

[30] T. Kitahara, T. Konomi, H. Nakajima, Microporous layer coated gas diffusion layers for enhanced performance of polymer electrolyte fuel cells, J. Power Sources 195 (2010) 2202-2211.

[31] J. T. Gostick, M. A. Ioannidis, M. W. Fowler, M. D. Pritzker, On the role of the microporous layer in PEMFC operation, Electrochem. Commun. 11 (2009) $576-579$.

[32] G. G. Park, Y. J. Sohn, T. H. Yang, Y. G. Yoon, W. Y. Lee, C. S. Kim, Effect of PTEF contents in the gas diffusion media on the performance of PEMFC, J. Power Sources 131 (2004) 182-187.

[33] C. Lim, C. Y. Wang, Effects of hydrophobic polymer content in GDL on power performance of a PEM fuel cell, Electrochim. Acta 49 (2004) 4149-4156.

[34] J. T. Gostick, M. A. Ioannidis, M. W. Fowler, M. D. Pritzker, Wettability and capillary behavior of fibrous gas diffusion media for polymer electrolyte fuel cells, 
J. Power Sources 194 (2009) 433-444.

[35] J. T. Gostick, M. A. Ioannidis, M. W. Fowler, M. D. Pritzker, Impact of liquid water on reactant mass transfer in PEM fuel cell electrodes, J. Electrochem. Soc. 157 (2010) B563-B571.

[36] S.A. Grigoriev, P. Millet, S. S. Volobuev, V. N. Fateev, Optimization of porous current collectors for PEM water electrolysers, Int. J. hydrogen Energy 34 (2009) 4968-4973.

[37] P. Argyropoulos, K. Scott, W. M. Taama, Carbon dioxide evolution patterns in direct methanol fuel cells, Electochim. Acta 44 (1999) 3575-3584.

[38] A. Oedegaard, C. Hebling, A. Schmitz, S. Møller-Holst, R. Tunold, Influence of diffusion layer properties on low temperature DMFC, J. Power Sources 127 (2004) 187-196.

[39] J. Zhang, G. P. Yin, Q. Z. Lai, Z. B. Wang, K. D. Cai, P. Liu, The influence of anode gas diffusion layer on the performance of low-temperature DMFC, J. Power Sources 168 (2007) 453-458.

[40] C. Xu, T. S. Zhao, Q. Ye, Effect of anode backing layer on the cell performance of a direct methanol fuel cell, Electochim. Acta 51 (2006) 5524-5431.

[41] G. Q. Lu, C. Y. Wang, Electrochemical and flow characterization of a direct methanol fuel cell, J. Power Sources 134 (2004) 33-40.

[42] American Society for Testing, Material Committee, Standard Test Methods, for Pore Size Characteristics of Membrane Filters by Bubble Point and Mean Flow Pore Test, ASTM, F316-89, 1970, pp. 722-727.

[43] M. F. Mathias, J. Roth, J. Fleming, W. Lehnert, Diffusion media materials and characterization, in: W. Vielstich, A. Lamm, H. A. Gasteiger (Eds.), Handbook of 
Fuel Cells, vol.3, John Wiley Sons Ltd., Chichester, 2003, pp. 517-537.

[44] M. V. Williams, H. R. Kunz, J. M. Fenton, Analysis of polarization curves to evaluate polarization sources in hydrogen/air PEM fuel cells, J. Electrochem. Soc. 152 (2005) A635-A644.

[45] L. J. J. Janssen, C. W. M. P. Sillen, E. Barendrecht, S. J. D. van Stralen, Bubble behavior during oxygen and hydrogen evolution at transparent electrodes in $\mathrm{KOH}$ solution, Electrochim. Acta, 29 (1984) 633-642.

[46] P. Boissonneau, P. Byrne, An experimental investigation of bubble-induced free convection in a small electrochemical cell, J. Appl. Electrochem. 30 (2000) 767-775.

[47] H. Ito, T. Maeda, A. Nakano, Y. Hasegawa, N. Yokoi, C. M. Hwang, M. Ishida, A. Kato, T. Yoshida, Effect of flow regime of circulating water on a proton exchange membrane electrolyzer, Int. J. Hydrog. Energy 35 (2010) 9550-9560.

[48] N.A.Kazakis, A.A. Mouza, S.V. Paras, Experimental study of bubble formation at metal porous spargers : Effect of liquid properties and sparger characteristics on the initial bubble size distribution, J. Chemical Engineering 137 (2008) 265-281.

[49] C. H. Song, H. C. No, M. k. Chung, Investigation of bubble flow developments and its transition based on the instability of void fraction waves, Int. J. Multiphase Flow 21 (1995) 381-404.

[50] S. Guet, G. Ooms, R. V. Oliemans, Influence of bubble size on the transition from low-Re bubbly flow to slug flow in a vertical pipe, Experimental Thermal and Fluid Science 26 (2002) 635-641.

[51] P. K. Sinha, P. Halleck, C. Y. Wang, Quantification of liquid water saturation in a PEM fuel cell diffusion medium using X-ray microtomography, Electrochem. 
Solid-State Lett. 10 (2006) A344-A348. 


\section{Acknowledgements}

The authors gratefully acknowledge the financial support from the New Energy and

Industrial Technology Development Organization (NEDO) of Japan. 


\section{Figure captions}

Figure 1. Schematic of a URFC with single-cell structure.

Figure 2. SEM images of (A) carbon-paper (Toray 090) and (B) Ti-felt (Bekinit) used for the GDL substrates. Ti-felt had a fiber diameter of $20 \mu \mathrm{m}$ and porosity of 0.75 .

Figure 3. Relation between PTFE concentration in emulsion and amount of PTFE loaded on GDL substrates of Ti-felt and carbon paper.

Figure 4. Polarization curves and overpotential separation into activation overpotential

$\left(\eta_{\text {act }}\right)$, ohmic overpotential $\left(\eta_{\text {ohm }}\right)$, and concentration overpotential $\left(\eta_{\text {cond }}\right)$, during fuel cell mode for a Ti-felt GDL of the oxygen electrode without PTFE treatment.

Figure 5. Current density (i) and voltage (V) characteristics during electrolysis mode.

(A) Effect of PTFE content and porosity of Ti-felt GDL ( $(\varepsilon)$ for the oxygen electrode with U1 (without PTFE treatment, $\varepsilon=0.75$ ), U2 (treated with 10wt\% PTFE emulsion, $\varepsilon=0.75$ ),

U3 (treated with 20wt\% PTFE emulsion, $\varepsilon=0.75$ ), and U6 (without PTFE treatment, 
$\varepsilon=0.50)$ cells, and (B) effect of fiber diameter $(\phi)$ of Ti-felt GDL without PTFE treatment with U1 $(\phi=20 \mu \mathrm{m}), \mathrm{U} 4(\phi=40 \mu \mathrm{m})$, and U6 $(\phi=80 \mu \mathrm{m})$ cells, cell temperature $\left(T_{\text {cell }}\right)$ was $80^{\circ} \mathrm{C}$.

Figure 6. Pore volume distribution in Ti-felt GDL substrates used in U1, U5, and U6 represented by pore diameter and logarithm of the differential volume $(=d V / d \log (d))$ measured using a mercury intrusion porosimeter (MIP).

Figure 7. Effect of humidification temperature $\left(T_{\text {fuel }}\right)$ of gases $\left(\mathrm{H}_{2}\right.$ and air $)$ on current density (i) and voltage ( $V$ ) characteristics during fuel cell mode of the U1 cell. In the U1 cell, the hydrogen-side GDL was carbon paper treated with 10 wt\% PTFE, and the oxygen-side GDL was Ti-felt without PTFE treatment. Cell temperature $\left(T_{\text {cell }}\right)$ was $80^{\circ} \mathrm{C}$.

Figure 8. Effect of humidification temperature $\left(T_{\text {fuel }}\right)$ on current density $(i)$ and overpotential characteristics for (A) activation overpotential $\left(\eta_{\text {act }}\right)$, (B) concentration overpotential ( $\left.\eta_{\text {conc }}\right)$, and $(C)$ ohmic overpotential $\left(\eta_{\text {ohm }}\right)$ during fuel cell mode with U1 cell. Cell temperature $\left(T_{\text {fuel }}\right)$ was $80^{\circ} \mathrm{C}$. 
Figure 9. Current density $(i)$ - activation overpotential $\left(\eta_{\text {act }}\right)$ characteristics during fuel cell mode for U1 U6 and F1 and F2 cells at humidification temperature $\left(T_{\text {fuel }}\right)$ of 70 and $75^{\circ} \mathrm{C}$. Cell temperature $\left(T_{\text {cell }}\right)$ was $80^{\circ} \mathrm{C}$.

Figure 10. Current density $(i)$ - ohmic overpotential $\left(\eta_{\text {ohm }}\right)$ characteristics during fuel cell mode for $\mathrm{U} 1 \sim \mathrm{U} 6$ and $\mathrm{F} 1$ and $\mathrm{F} 2$ cells at humidification temperature $\left(T_{\text {fuel }}\right)$ of 70 and $75^{\circ} \mathrm{C}$. Cell temperature $\left(T_{\text {cell }}\right)$ was $80^{\circ} \mathrm{C}$.

Figure 11. Effect of PTFE content in Ti-felt GDL substrates of the oxygen electrode on current density (i) - voltage (V) characteristics during fuel cell mode for U1, U2, and U3 cells at humidification temperature $\left(T_{\text {fuel }}\right)$ of $(\mathrm{A}) 70^{\circ} \mathrm{C}$ and $(\mathrm{B}) 75^{\circ} \mathrm{C}$. The Ti-felt GDL in U1 is not treated with PTFE, and the Ti-felt in U2 and U3 is treated with PTFE emulsion of 10 (U2) and $20 \mathrm{wt} \%$ (U3) concentration, respectively. Cell temperature $\left(T_{\text {cell }}\right)$ was $80^{\circ} \mathrm{C}$. F1 cell is also plotted for reference.

Figure 12. Effect of PTFE content in Ti-felt GDL substrates of the oxygen electrode on current density $(i)$ - concentration overpotential $\left(\eta_{\text {cond }}\right)$ characteristics during fuel cell 
mode for $\mathrm{U} 1, \mathrm{U} 2, \mathrm{U} 3$, and F1 cells at humidification temperature $\left(T_{\text {fuel }}\right)$ of 70 and $75^{\circ} \mathrm{C}$.

Cell temperature $\left(T_{\text {cell }}\right)$ was $80^{\circ} \mathrm{C}$. $\eta_{\text {conc }}$ was calculated from the $i-V$ data shown in Fig. 11.

Figure 13. Effect of PTFE content in carbon-paper GDL substrates of the oxygen electrode on current density $(i)$ - voltage $(V)$ characteristics during fuel cell mode for F1 and $\mathrm{F} 2$ cells at humidification temperature $\left(T_{\text {fuel }}\right)$ of $(\mathrm{A}) 70^{\circ} \mathrm{C}$ and $(\mathrm{B}) 75^{\circ} \mathrm{C}$, The carbon paper GDL of the oxygen electrode is not treated with PTFE in F1, and the one is treated with 10wt.\% PTFE emulsion in F2.when the cell temperature is $80^{\circ} \mathrm{C}$.

Figure 14. Liquid water saturation $(s)$ versus capillary pressure $(P c)$ characteristics with the Toray 090 substrate presented by Gostick et al. [34], (-o-) : Toray 090 without PTFE treatment. (-口-) : Toray 090 with PTFE 20wt.\%.

Figure 15. Effect of fiber diameter $(\phi)$ of the Ti-felt GDL of the oxygen electrode on the current density $(i)$ - voltage $(V)$ characteristics during fuel cell mode for U1, U4, and U5 cells (with no PTFE treatment) at humidification temperature $\left(T_{\text {fuel }}\right)$ of $(\mathrm{A}) 70^{\circ} \mathrm{C}$ and $(\mathrm{B})$ $75^{\circ} \mathrm{C}$. Cell temperature $\left(T_{\text {cell }}\right)$ was $80^{\circ} \mathrm{C}$. 
Figure 16. Effect of fiber diameter $(\phi)$ of the Ti-felt GDL of the oxygen electrode on the current density $(i)$ - concentration overpotential $\left(\eta_{\text {cond }}\right)$ characteristics during fuel cell mode for U1, U4, and U5 cells (with no PTFE treatment) at humidification temperature ( $\left.T_{\text {fuel }}\right)$ of $75^{\circ} \mathrm{C}$. Cell temperature $\left(T_{\text {cell }}\right)$ was $80^{\circ} \mathrm{C}$. $\eta_{\text {conc }}$ was calculated from the $i-V$ data shown in Fig. 15(B).

Figure 17. Effect of porosity $(\varepsilon)$ of the Ti-felt GDL of the oxygen electrode on the current density $(i)$ - voltage $(V)$ characteristics during fuel cell mode for U1 and U6 cells at humidification temperature $\left(T_{\text {fuel }}\right)$ of $(\mathrm{A}) 70^{\circ} \mathrm{C}$ and $(\mathrm{B}) 75^{\circ} \mathrm{C}$. Cell temperature $\left(T_{\text {cell }}\right)$ was $80^{\circ} \mathrm{C}$. The Ti-felt GDLs were not treated with PTFE, and had fiber diameter $(\phi)$ of $20 \mu \mathrm{m}$.

Figure 18. Effect of porosity $(\varepsilon)$ of the Ti-felt GDL of the oxygen electrode on the current density $(i)$ - concentration overpotential $\left(\eta_{\text {conc }}\right)$ characteristics during fuel cell mode for $\mathrm{U} 1$ and $\mathrm{U} 6$ cells at humidification temperature $\left(T_{\text {fuel }}\right)$ of $75^{\circ} \mathrm{C}$. Cell temperature $\left(T_{\text {cell }}\right)$ was $80^{\circ} \mathrm{C} . \eta_{\text {conc }}$ was calculated from the $i-V$ data shown in Fig. $17(\mathrm{~B})$.

Figure 19. Schematic of liquid water and air transport for different Ti-felt GDL 
substrates (A) with uniform pore distribution structure as in U1 (B) with ununiform pore distribution pore distribution as in U4, U5, and U6.

Figure 20. Effect of fiber diameter $(\phi)$ and porosity $(\varepsilon)$ of Ti-felt GDLs on the current density $(i)$ and round-trip efficiency $\left(\eta_{\mathrm{RT}}\right)$ during electrolysis and fuel cell modes for U1, U5, and U6 cells at humidification temperature $\left(T_{\text {fuel }}\right)$ of $(\mathrm{A}) 70$ and $(\mathrm{B}) 75^{\circ} \mathrm{C}$. Cell temperature $\left(T_{\text {cell }}\right)$ was $80^{\circ} \mathrm{C}$.

Table I. GDL properties at the oxygen electrode for the URFC performance test a).

Table II. Operating conditions of URFC during electrolysis and fuel cell modes. 


\section{Figure 1}

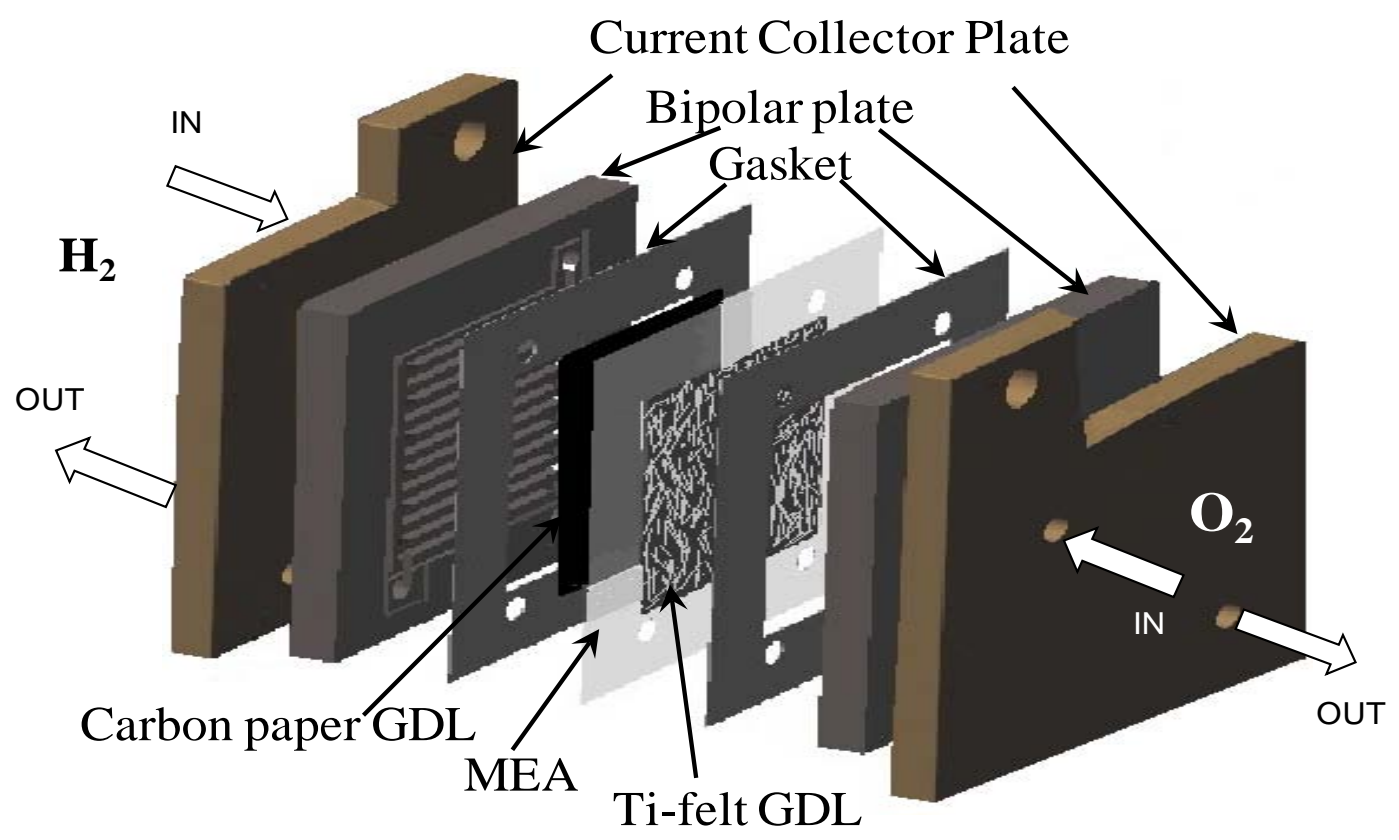

Figure 1. Schematic of a URFC with single-cell structure. 
Figure 2

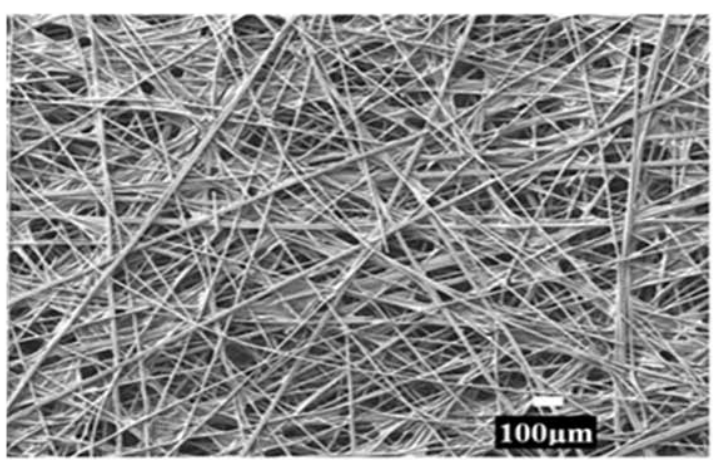

(A) Carbon paper GDL

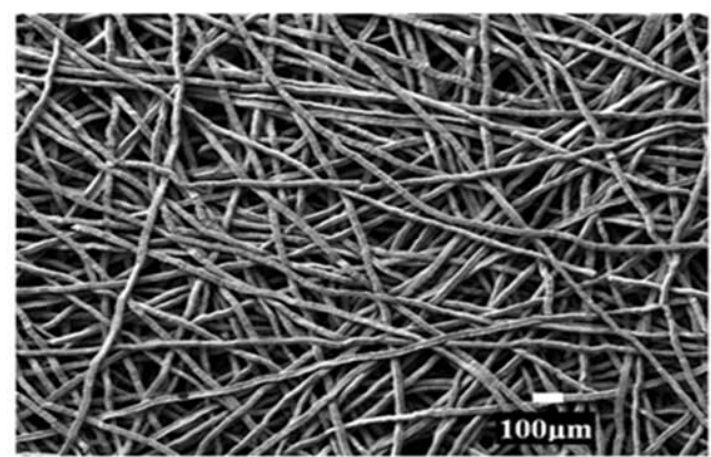

(B) Ti-felt GDL

(B) Titanium-felt GDL

(A) Carbon-paper GDL

Figure 2. SEM images of (A) carbon-paper (Toray 090) and (B) Ti-felt (Bekinit) used for the GDL substrates. Ti-felt had a fiber diameter of $20 \mu \mathrm{m}$ and porosity of 0.75 . 
Figure 3

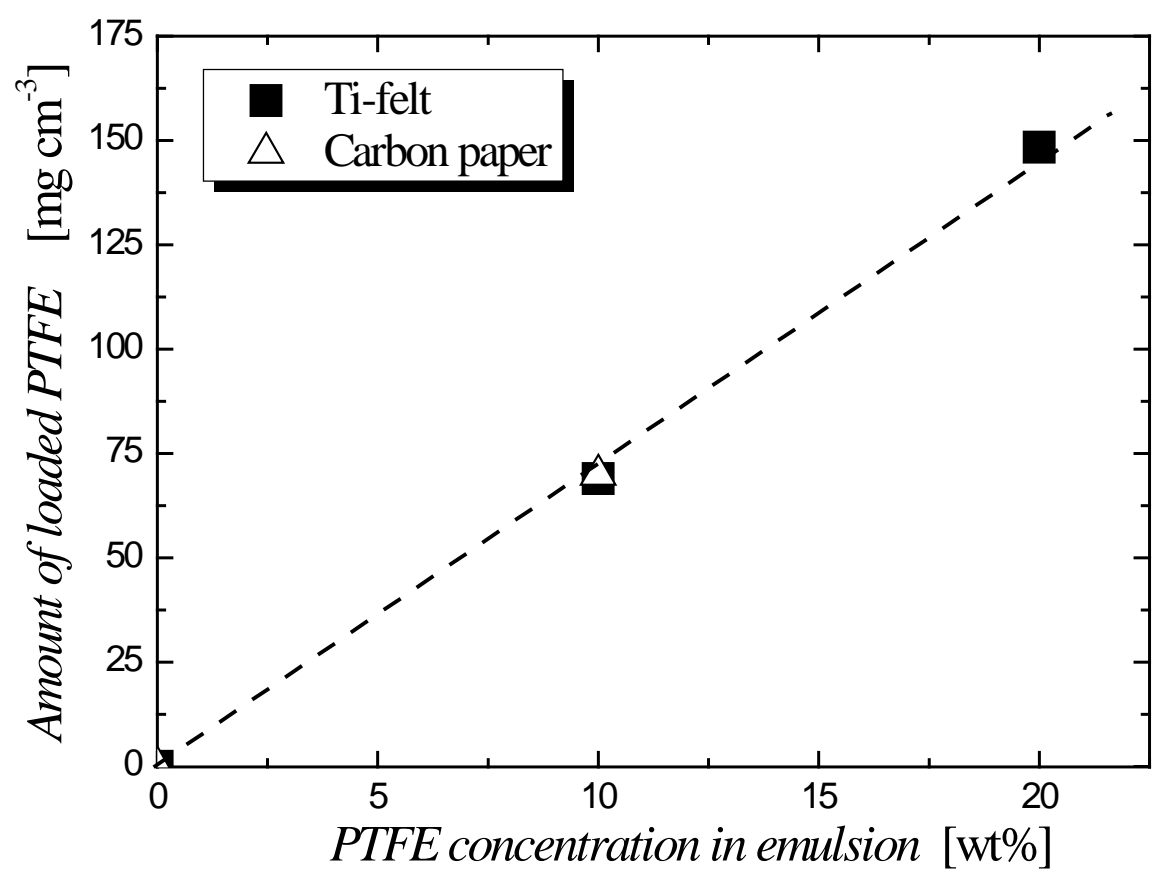

Figure 3. Relation between PTFE concentration in emulsion and amount of PTFE loaded on GDL substrates of Ti-felt and carbon paper. 
Figure 4

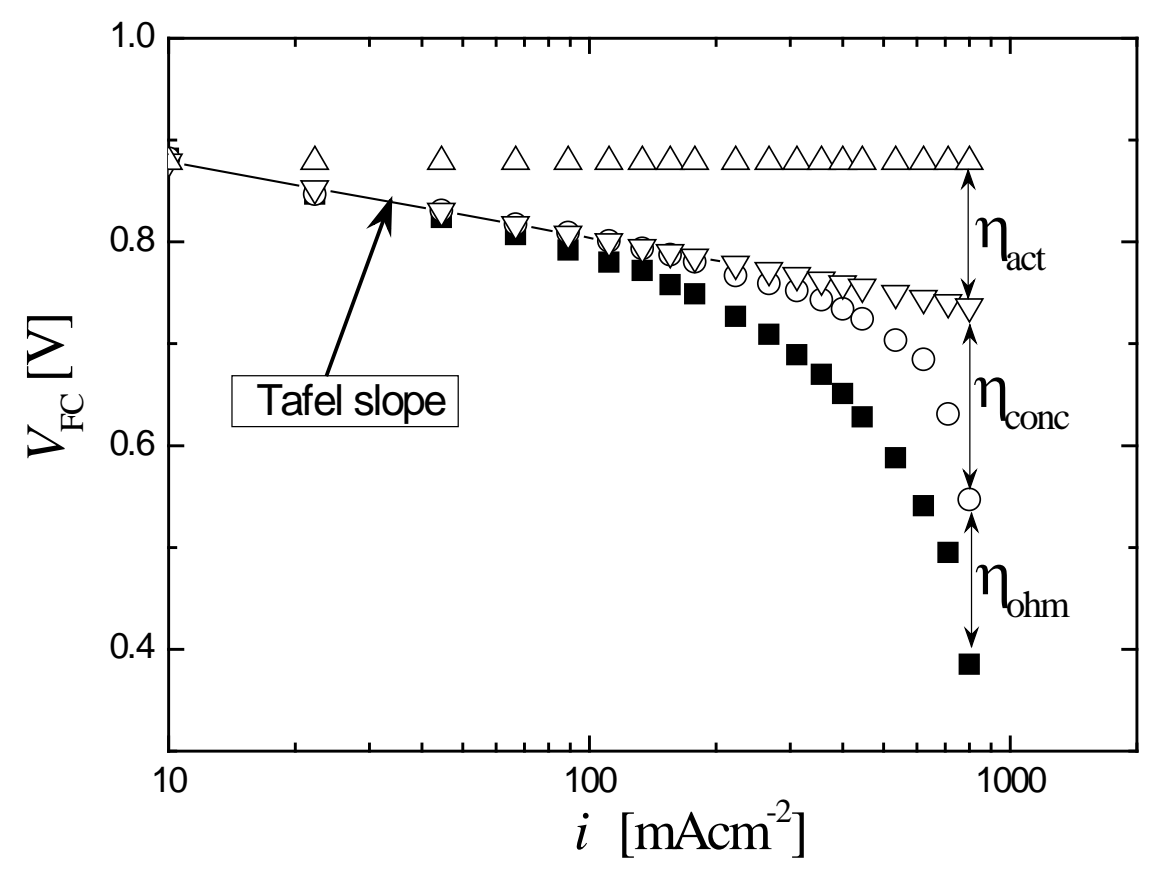

Figure 4. Polarization curves and overpotential separation into activation overpotential $\left(\eta_{\text {act }}\right)$, ohmic overpotential $\left(\eta_{\text {ohm }}\right)$, and concentration overpotential $\left(\eta_{\text {conc }}\right)$, during fuel cell mode for a Ti-felt GDL of the oxygen electrode without PTFE treatment. 


\section{Figure 5}
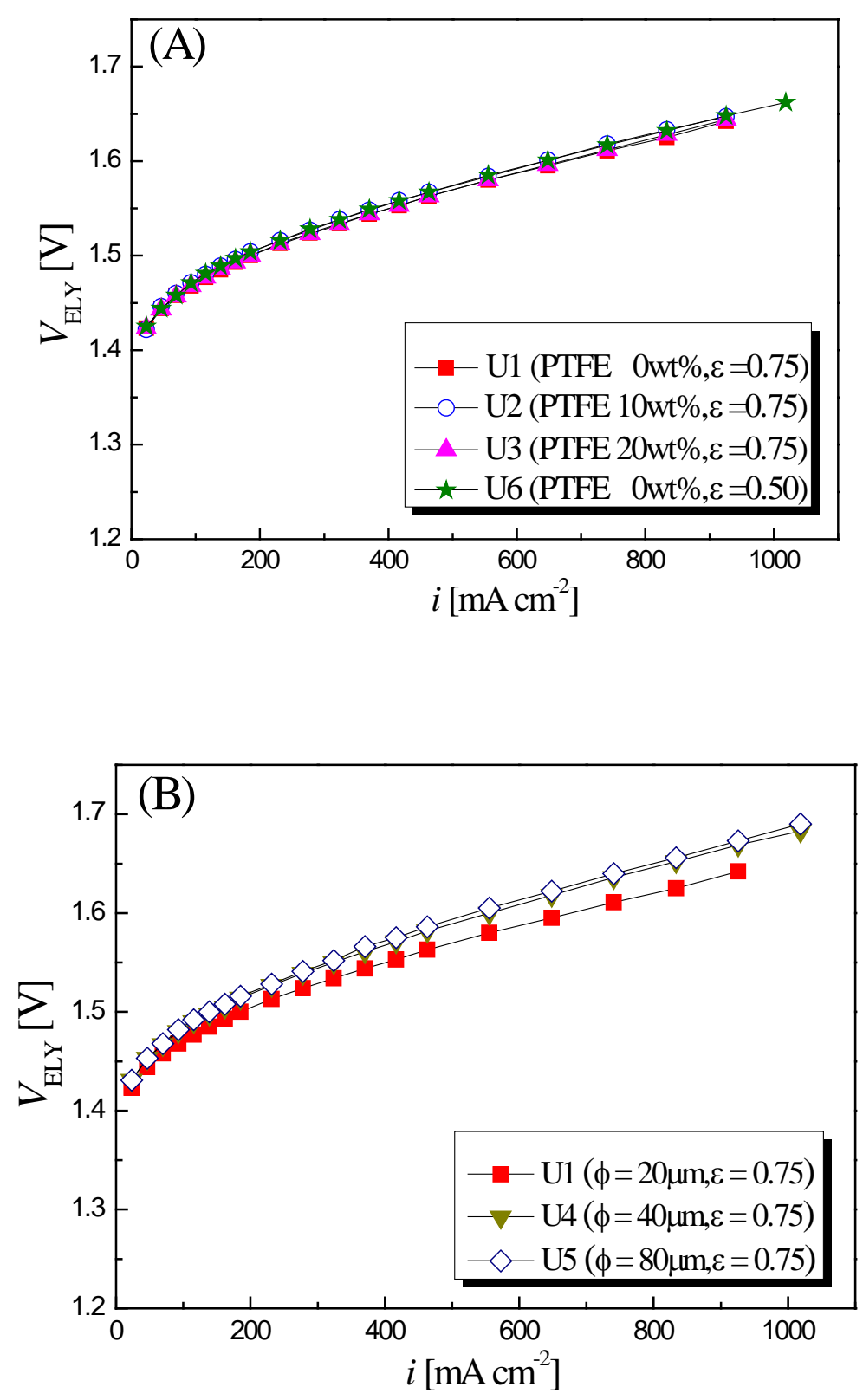

Figure 5. Current density $(i)$ and voltage $(V)$ characteristics during electrolysis mode. (A) Effect of PTFE content and porosity of Ti-felt GDL ( $\varepsilon$ ) for the oxygen electrode with U1 (without PTFE treatment, $\varepsilon=0.75$ ), U2 (treated with 10wt\% PTFE emulsion, $\varepsilon=0.75$ ), U3 (treated with $20 \mathrm{wt} \%$ PTFE emulsion, $\varepsilon=0.75$ ), and U6 (without PTFE treatment, $\varepsilon=0.50)$ cells, and (B) effect of fiber diameter $(\phi)$ of Ti-felt GDL without PTFE treatment with U1 $(\phi=20 \mu \mathrm{m}), \mathrm{U} 4(\phi=40 \mu \mathrm{m})$, and U6 $(\phi=80 \mu \mathrm{m})$ cells, cell temperature $\left(T_{\text {cell }}\right)$ was $80^{\circ} \mathrm{C}$. 


\section{Figure 6}

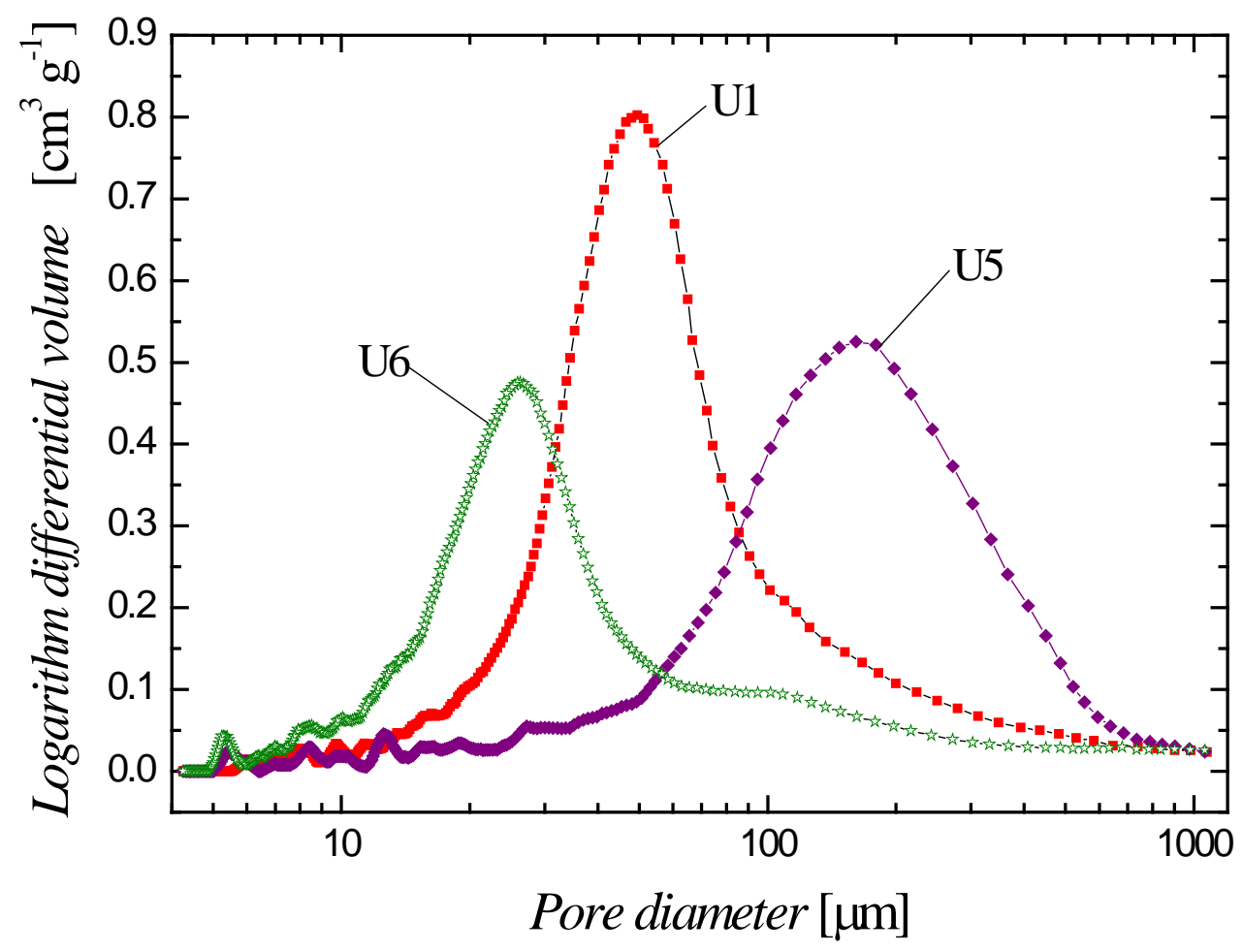

Figure 6. Pore volume distribution in Ti-felt GDL substrates used in U1, U5, and U6 represented by pore diameter and logarithm of the differential volume $(=d V / d \log (d))$ measured using a mercury intrusion porosimeter (MIP). 


\section{Figure 7}

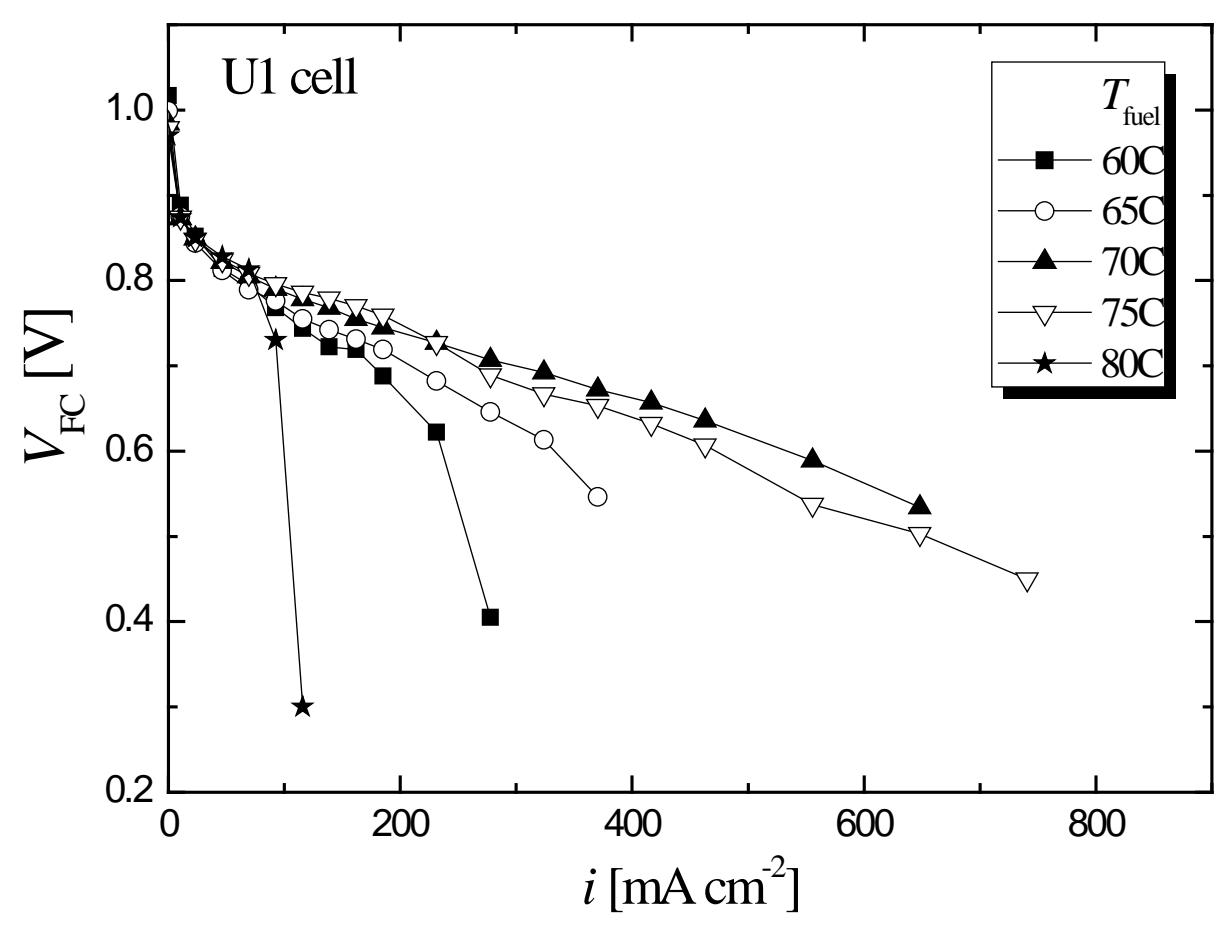

Figure 7. Effect of humidification temperature $\left(T_{\text {fuel }}\right)$ of gases $\left(\mathrm{H}_{2}\right.$ and air $)$ on current density $(i)$ and voltage $(V)$ characteristics during fuel cell mode of the U1 cell. In the U1 cell, the hydrogen-side GDL was carbon paper treated with $10 \mathrm{wt} \%$ PTFE, and the oxygen-side GDL was Ti-felt without PTFE treatment. Cell temperature $\left(T_{\text {cell }}\right)$ was $80^{\circ} \mathrm{C}$. 


\section{Figure 8}

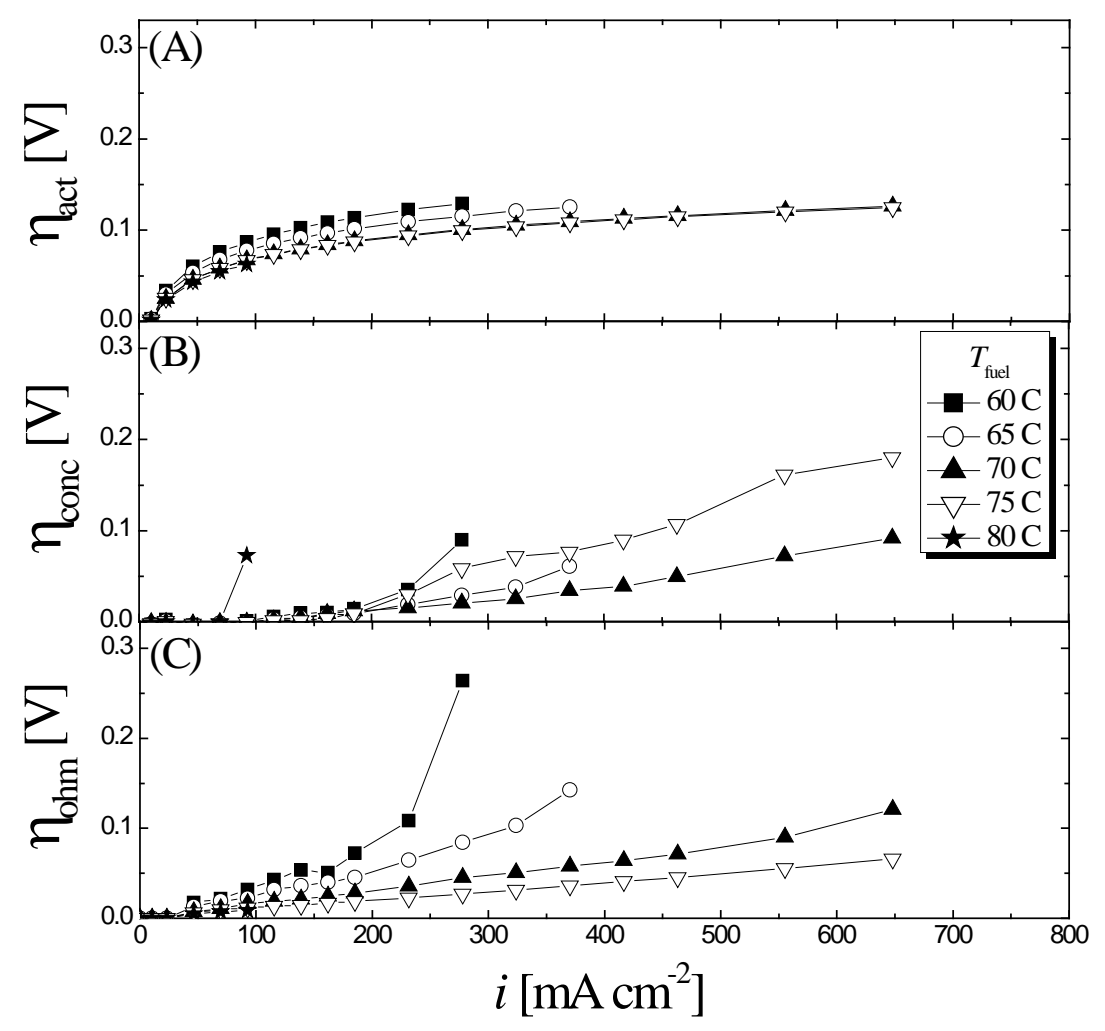

Figure 8. Effect of humidification temperature $\left(T_{\text {fuel }}\right)$ on current density $(i)$ and overpotential characteristics for $(A)$ activation overpotential $\left(\eta_{\mathrm{act}}\right)$, (B) concentration overpotential $\left(\eta_{\text {conc }}\right.$ ), and $(C)$ ohmic overpotential $\left(\eta_{\text {ohm }}\right)$ during fuel cell mode with U1 cell. Cell temperature $\left(T_{\text {fuel }}\right)$ was $80^{\circ} \mathrm{C}$. 


\section{Figure 9}

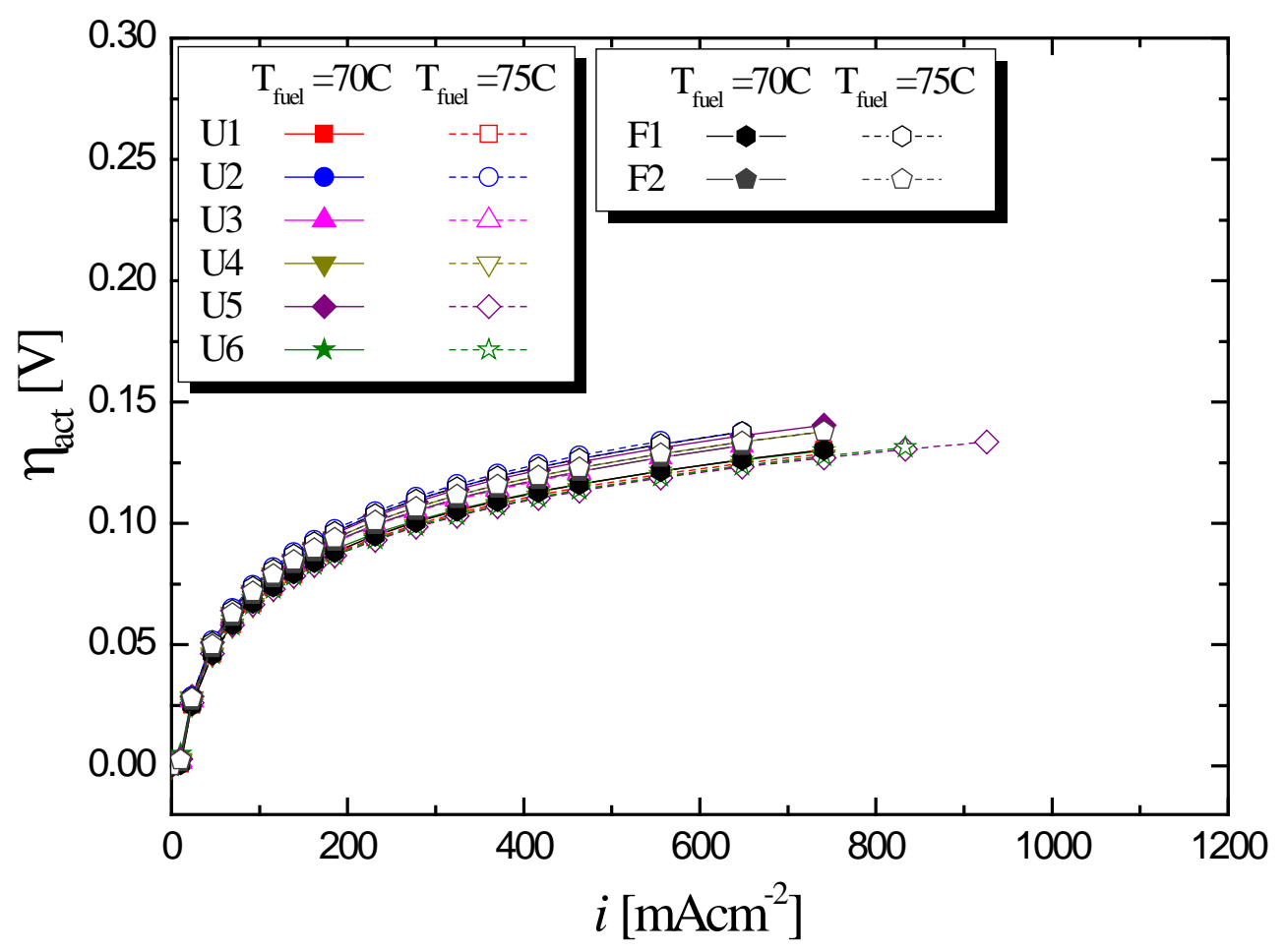

Figure 9. Current density $(i)$ - activation overpotential $\left(\eta_{\text {act }}\right)$ characteristics during fuel cell mode for $\mathrm{U} 1 \sim \mathrm{U} 6$ and $\mathrm{F} 1$ and $\mathrm{F} 2$ cells at humidification temperature $\left(T_{\text {fuel }}\right)$ of 70 and $75^{\circ} \mathrm{C}$. Cell temperature $\left(T_{\text {cell }}\right)$ was $80^{\circ} \mathrm{C}$. 
Figure 10

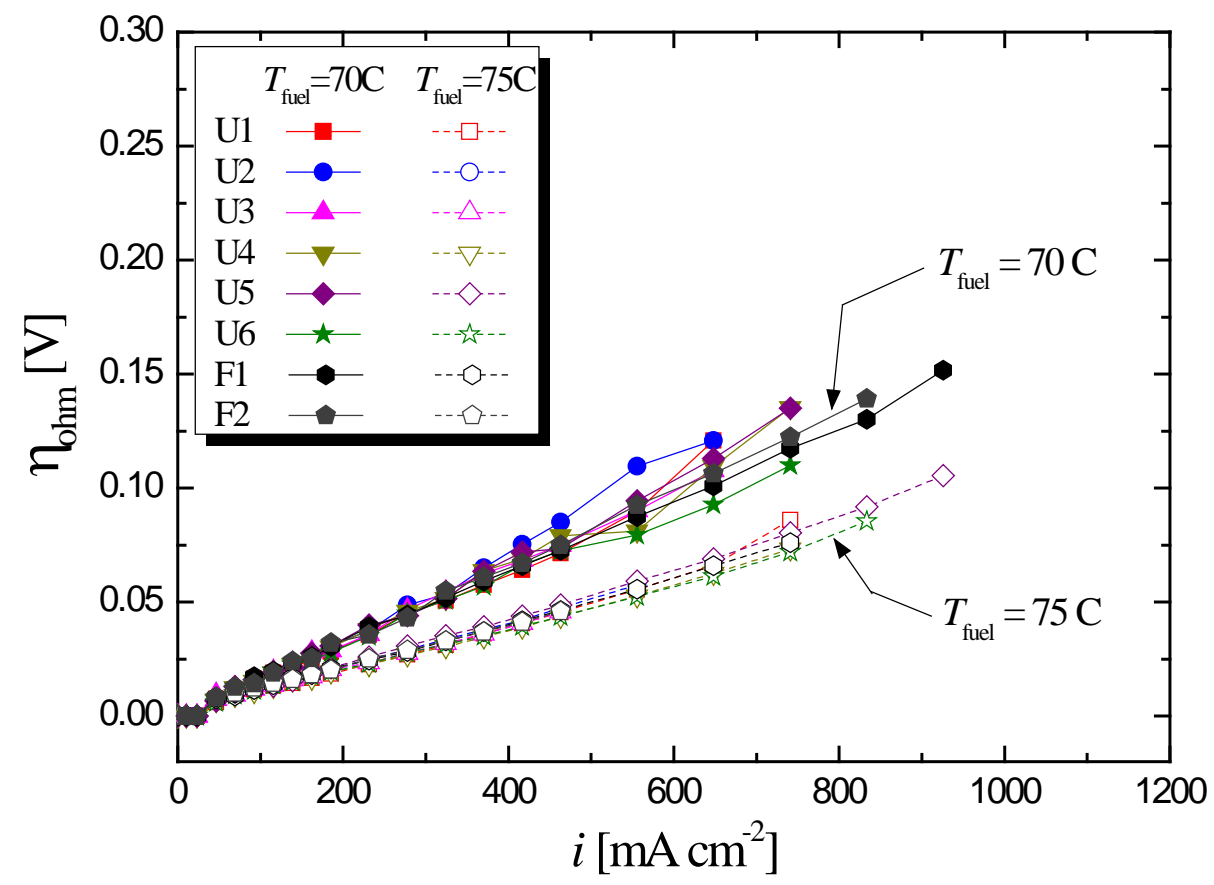

Figure 10. Current density $(i)$ - ohmic overpotential $\left(\eta_{\text {ohm }}\right)$ characteristics during fuel cell mode for U1 U6 and F1 and F2 cells at humidification temperature $\left(T_{\text {fuel }}\right)$ of 70 and $75^{\circ} \mathrm{C}$. Cell temperature $\left(T_{\text {cell }}\right)$ was $80^{\circ} \mathrm{C}$. 
Figure 11

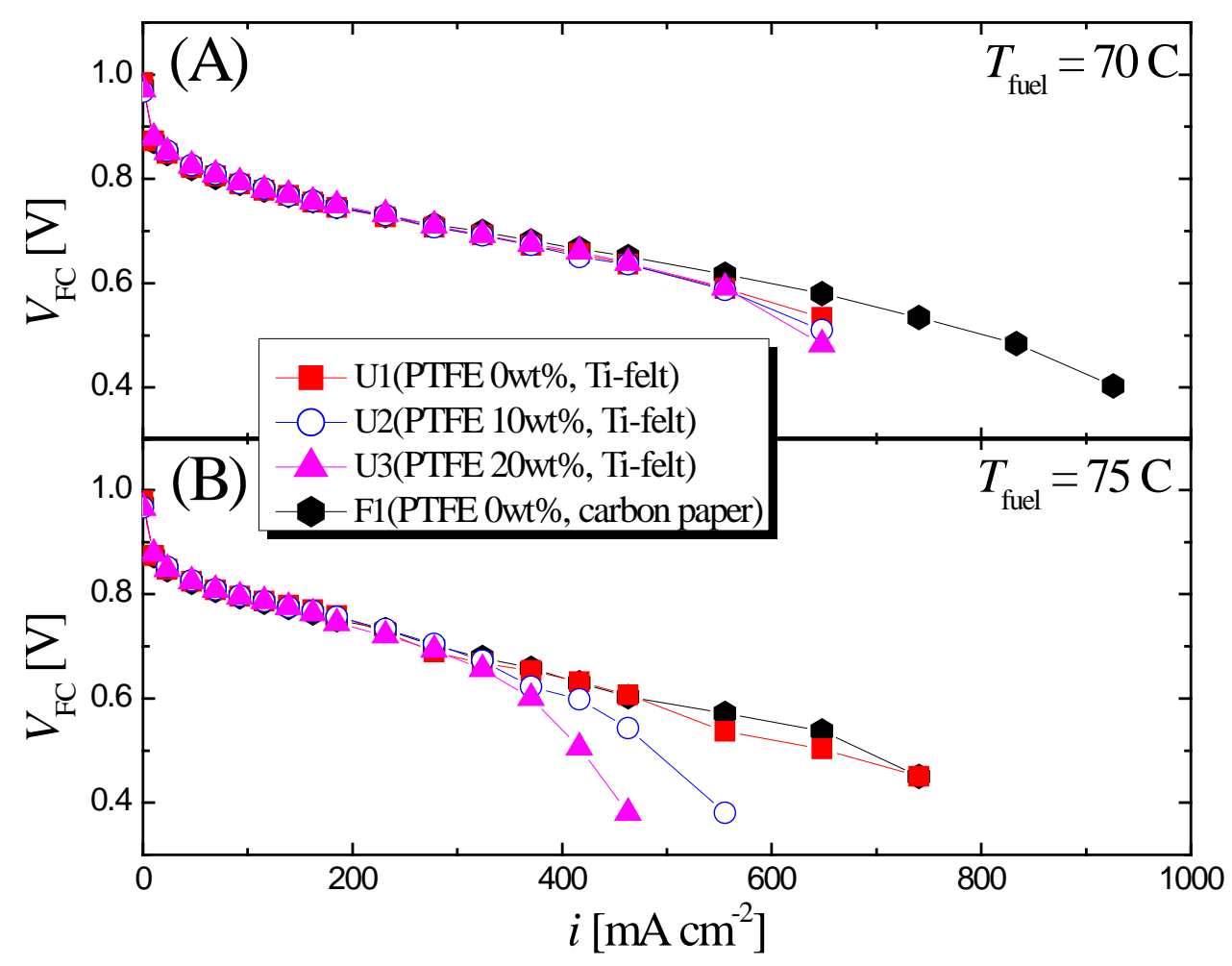

Figure 11. Effect of PTFE content in Ti-felt GDL substrates of the oxygen electrode on current density $(i)$ - voltage $(V)$ characteristics during fuel cell mode for U1, U2, and $\mathrm{U} 3$ cells at humidification temperature $\left(T_{\text {fuel }}\right)$ of $(\mathrm{A}) 70^{\circ} \mathrm{C}$ and $(\mathrm{B}) 75^{\circ} \mathrm{C}$. The Ti-felt GDL in U1 is not treated with PTFE, and the Ti-felt in U2 and U3 is treated with PTFE emulsion of 10 (U2) and $20 \mathrm{wt} \%$ (U3) concentration, respectively. Cell temperature $\left(T_{\text {cell }}\right)$ was $80^{\circ} \mathrm{C}$. F1 cell is also plotted for reference. 


\section{Figure 12}

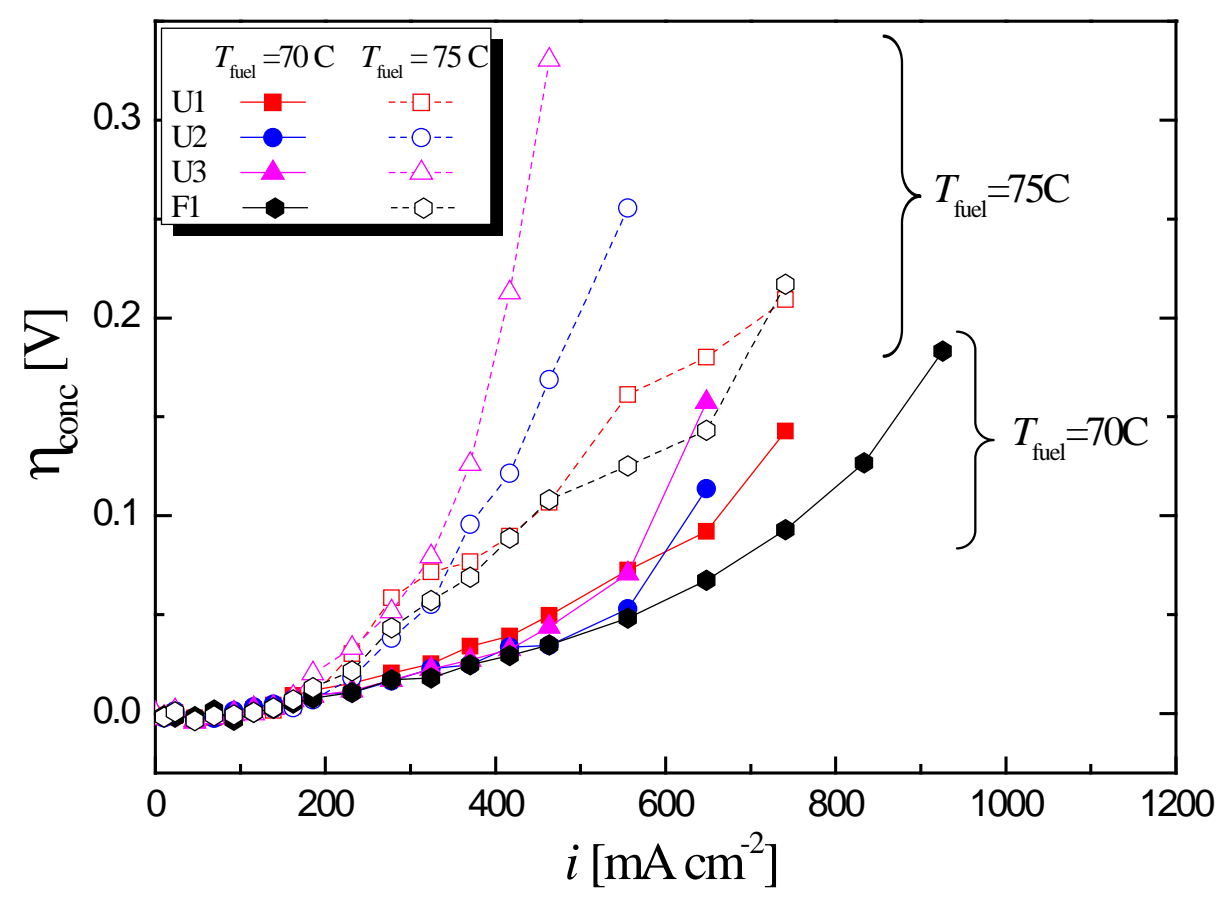

Figure 12. Effect of PTFE content in Ti-felt GDL substrates of the oxygen electrode on current density $(i)$ - concentration overpotential $\left(\eta_{\text {conc }}\right)$ characteristics during fuel cell mode for U1, U2, U3, and F1 cells at humidification temperature $\left(T_{\text {fuel }}\right)$ of 70 and $75^{\circ} \mathrm{C}$. Cell temperature $\left(T_{\text {cell }}\right)$ was $80^{\circ} \mathrm{C}$. $\eta_{\text {conc }}$ was calculated from the $i-V$ data shown in Fig. 11. 


\section{Figure 13}

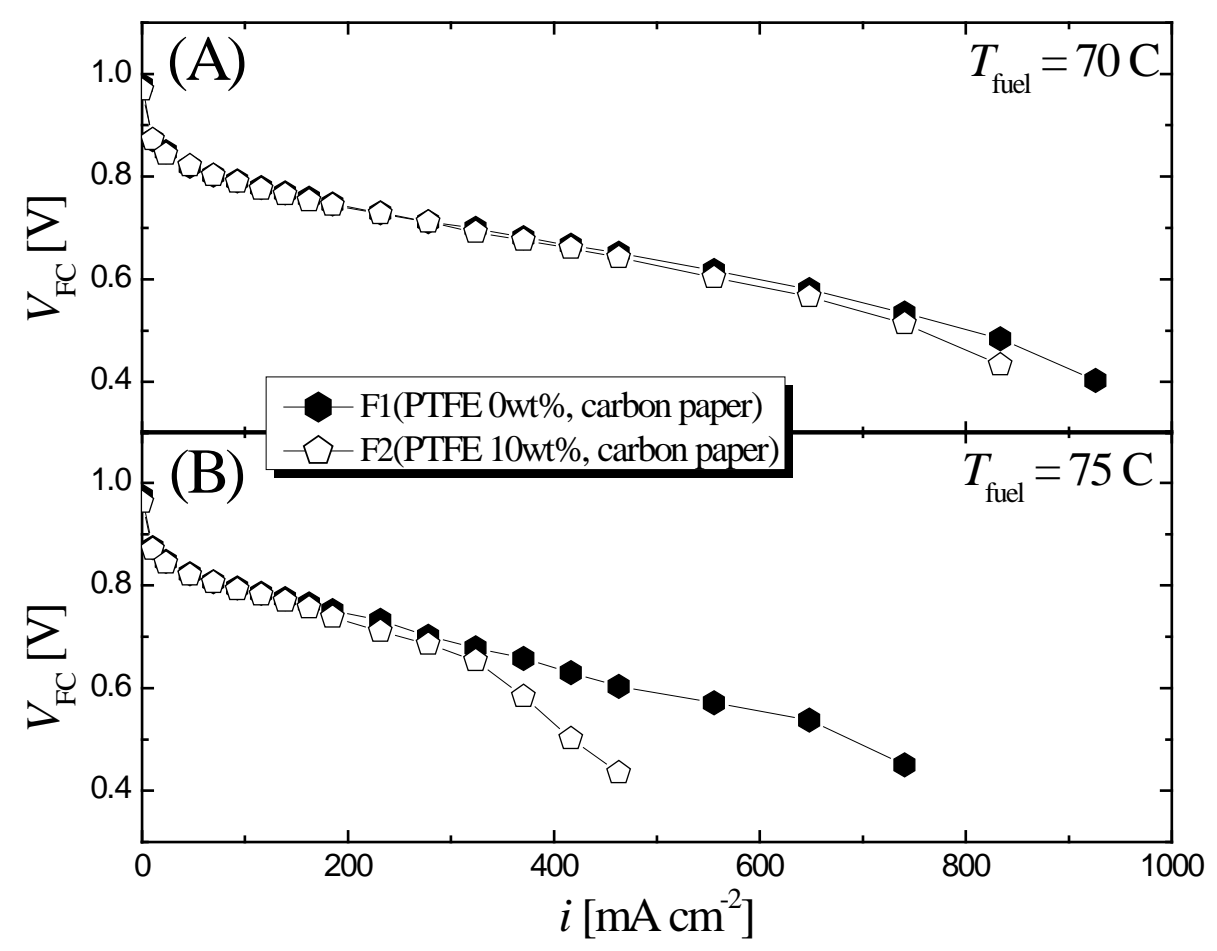

Figure 13. Effect of PTFE content in carbon-paper GDL substrates of the oxygen electrode on current density $(i)$ - voltage $(V)$ characteristics during fuel cell mode for F1 and $\mathrm{F} 2$ cells at humidification temperature $\left(T_{\text {fuel }}\right)$ of $(\mathrm{A}) 70^{\circ} \mathrm{C}$ and $(\mathrm{B}) 75^{\circ} \mathrm{C}$, The carbon paper GDL of the oxygen electrode is not treated with PTFE in F1, and the one is treated with 10wt.\% PTFE emulsion in F2.when the cell temperature is $80^{\circ} \mathrm{C}$. 


\section{Figure 14}

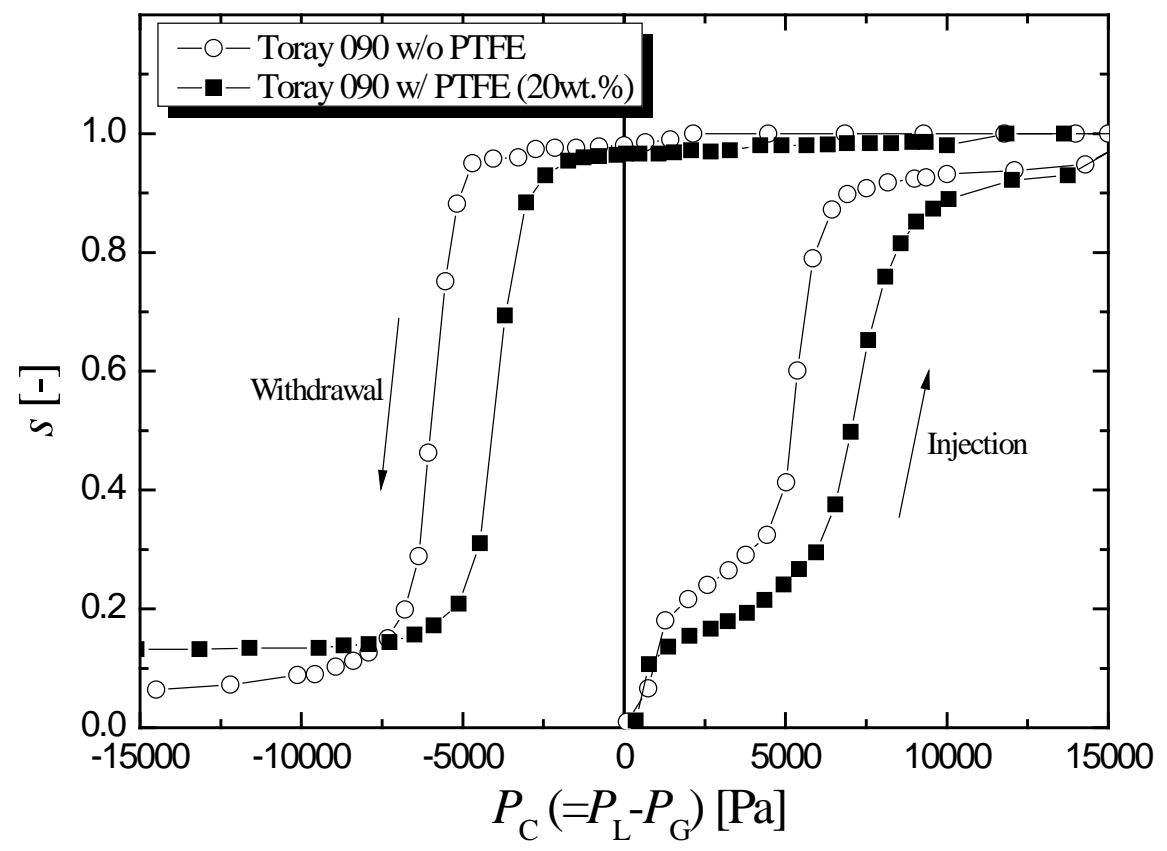

Figure 14. Liquid water saturation $(s)$ versus capillary pressure $(P c)$ characteristics with the Toray 090 substrate presented by Gostick et al. [34], (-o-) : Toray 090 without PTFE treatment. (--) : Toray 090 with PTFE 20wt.\%. 
Figure 15

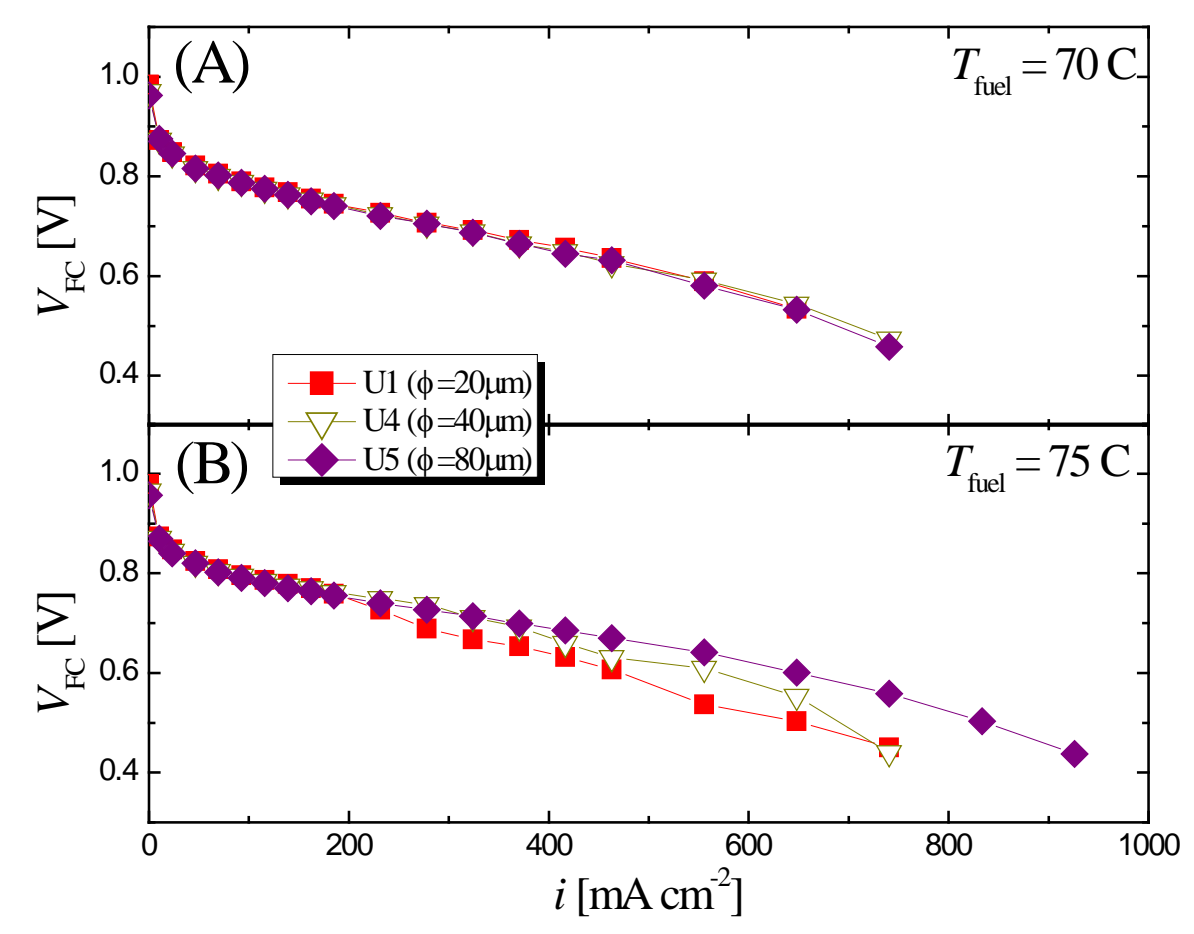

Figure 15. Effect of fiber diameter $(\phi)$ of the Ti-felt GDL of the oxygen electrode on the current density $(i)$ - voltage $(V)$ characteristics during fuel cell mode for U1, U4, and U5 cells (with no PTFE treatment) at humidification temperature $\left(T_{\text {fuel }}\right)$ of $(\mathrm{A}) 70^{\circ} \mathrm{C}$ and (B) $75^{\circ} \mathrm{C}$. Cell temperature $\left(T_{\text {cell }}\right)$ was $80^{\circ} \mathrm{C}$. 


\section{Figure 16}

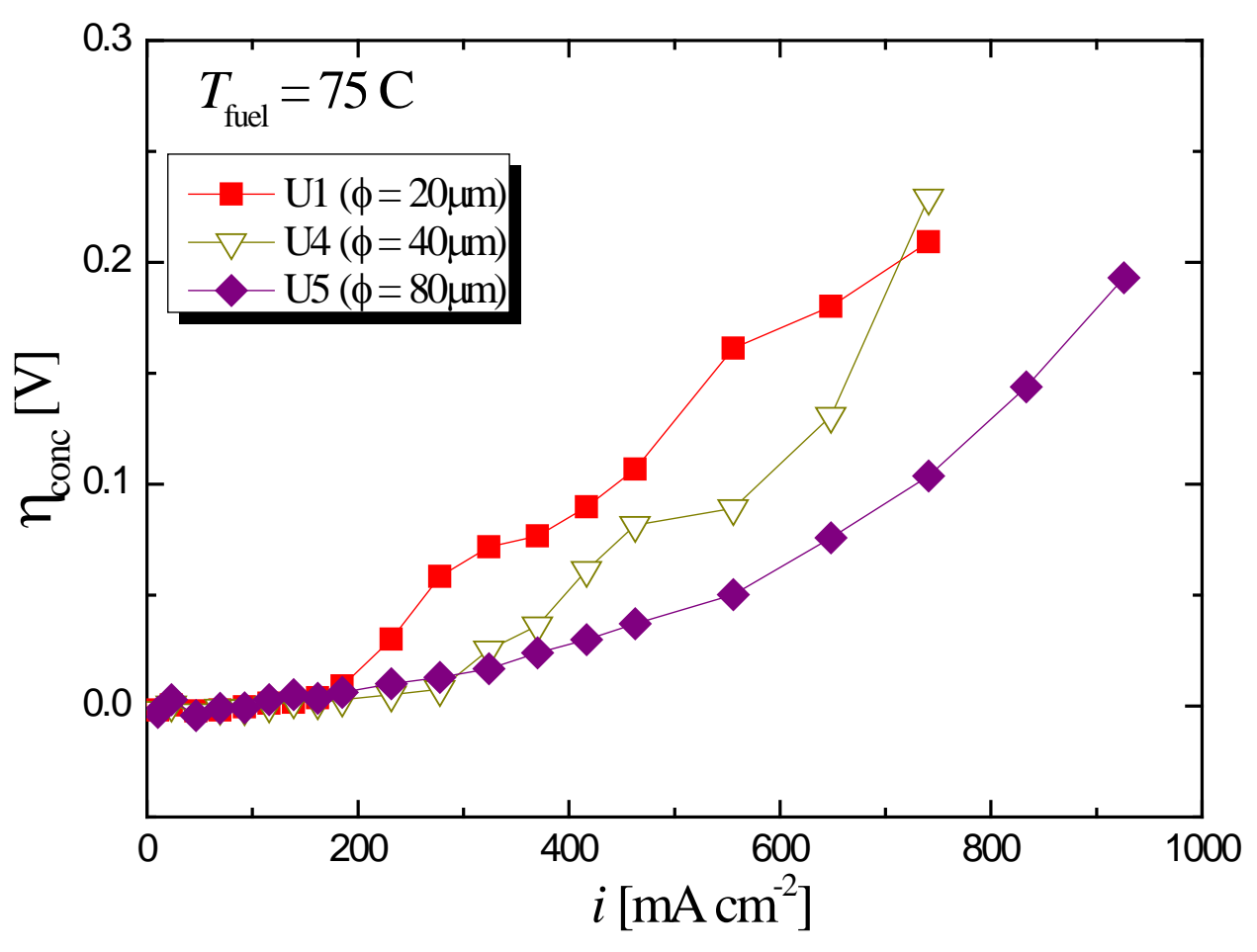

Figure 16. Effect of fiber diameter $(\phi)$ of the Ti-felt GDL of the oxygen electrode on the current density $(i)$ - concentration overpotential ( $\eta_{\text {conc }}$ ) characteristics during fuel cell mode for U1, U4, and U5 cells (with no PTFE treatment) at humidification temperature $\left(T_{\text {fuel }}\right)$ of $75^{\circ} \mathrm{C}$. Cell temperature $\left(T_{\text {cell }}\right)$ was $80^{\circ} \mathrm{C} . \eta_{\text {conc }}$ was calculated from the $i-V$ data shown in Fig. 15(B). 


\section{Figure 17}

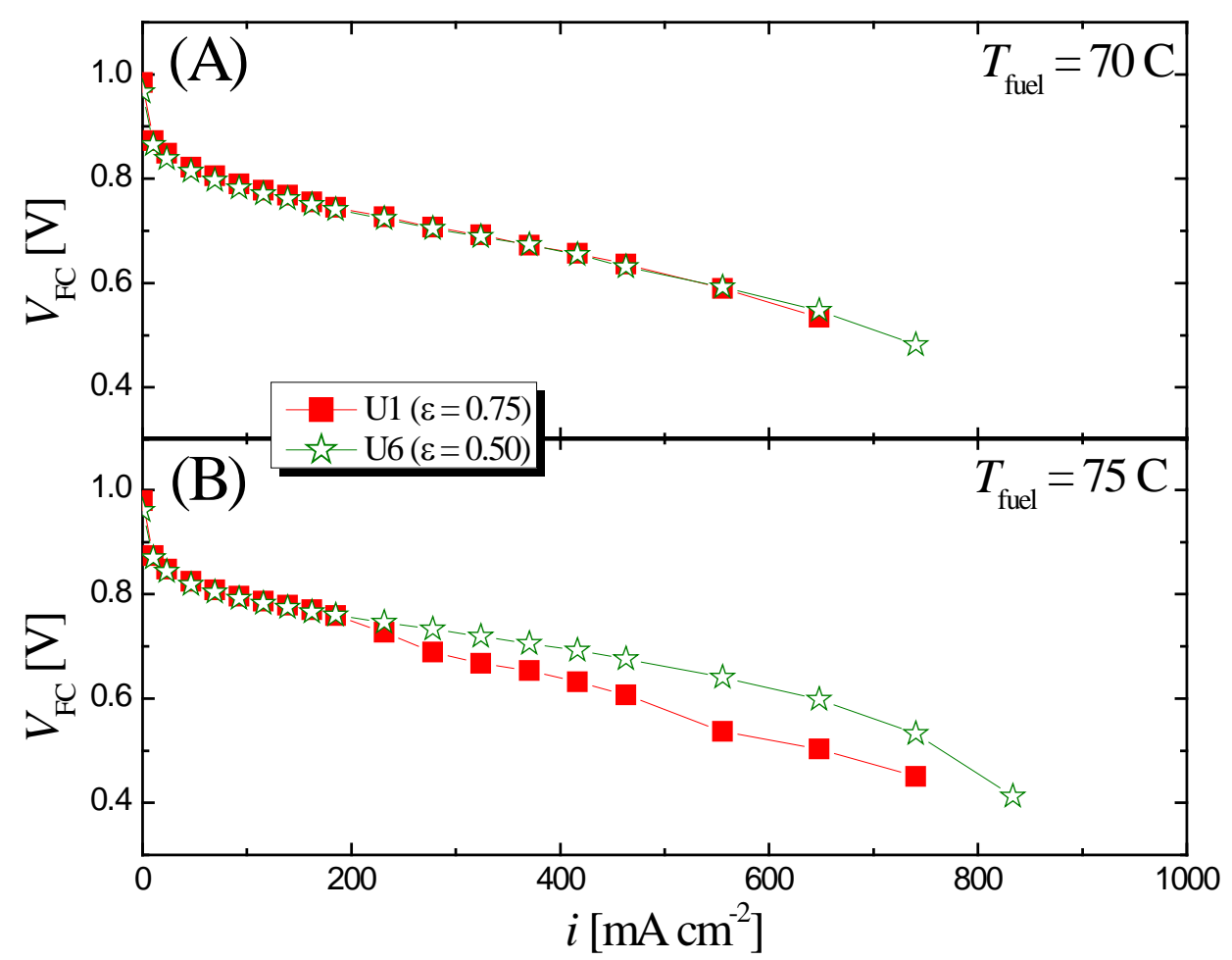

Figure 17. Effect of porosity $(\varepsilon)$ of the Ti-felt GDL of the oxygen electrode on the current density $(i)$ - voltage $(V)$ characteristics during fuel cell mode for U1 and U6 cells at humidification temperature $\left(T_{\text {fuel }}\right)$ of $(\mathrm{A}) 70^{\circ} \mathrm{C}$ and $(\mathrm{B}) 75^{\circ} \mathrm{C}$. Cell temperature $\left(T_{\text {cell }}\right)$ was $80^{\circ} \mathrm{C}$. The Ti-felt GDLs were not treated with PTFE, and had fiber diameter ( $\phi)$ of $20 \mu \mathrm{m}$. 


\section{Figure 18}

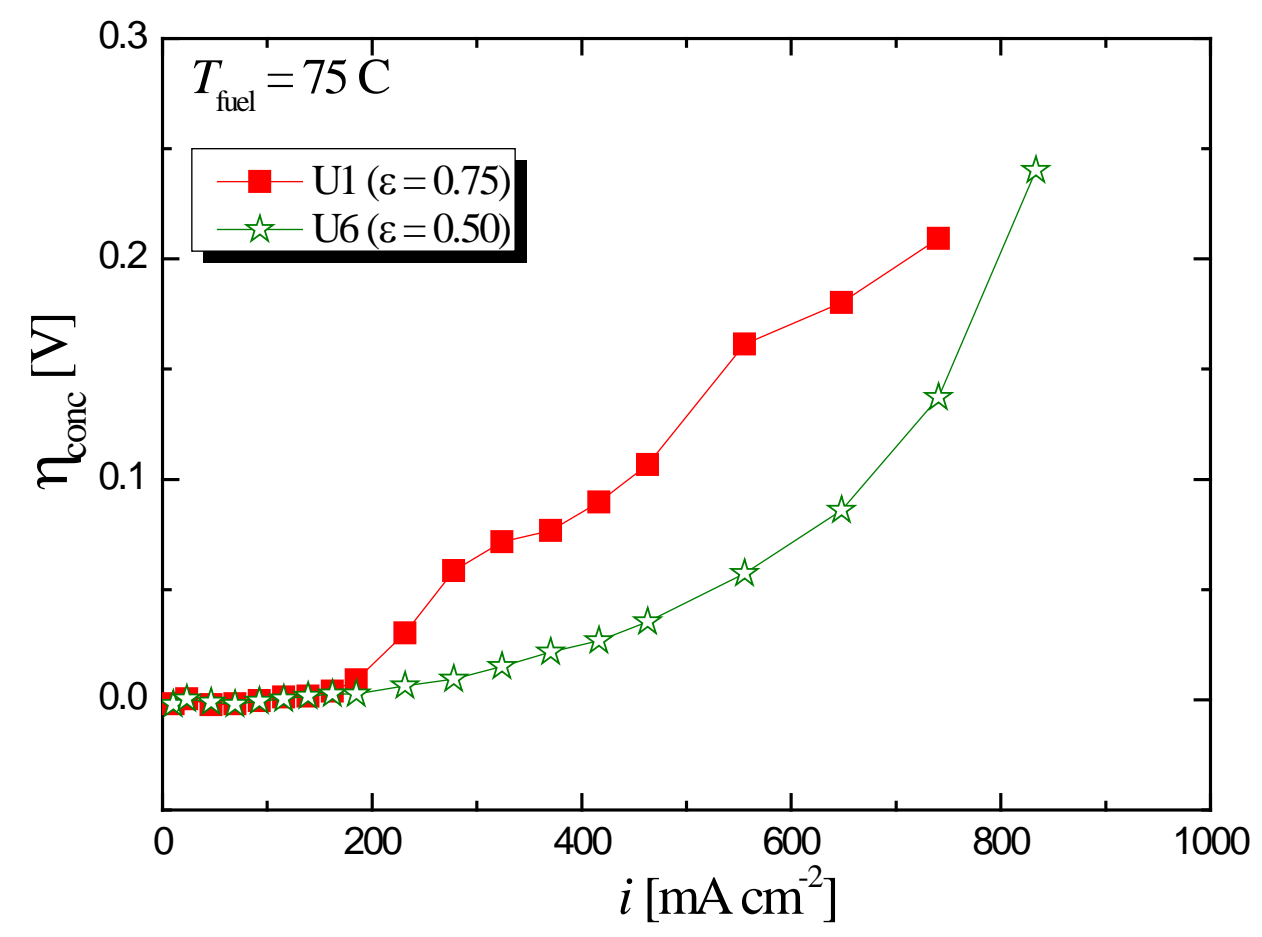

Figure 18. Effect of porosity $(\varepsilon)$ of the Ti-felt GDL of the oxygen electrode on the current density $(i)$ - concentration overpotential $\left(\eta_{\text {cond }}\right)$ characteristics during fuel cell mode for $\mathrm{U} 1$ and $\mathrm{U} 6$ cells at humidification temperature $\left(T_{\text {fuel }}\right)$ of $75^{\circ} \mathrm{C}$. Cell temperature $\left(T_{\text {cell }}\right)$ was $80^{\circ} \mathrm{C}$. $\eta_{\text {conc }}$ was calculated from the $i-V$ data shown in Fig. 17(B). 


\section{Figure 19}

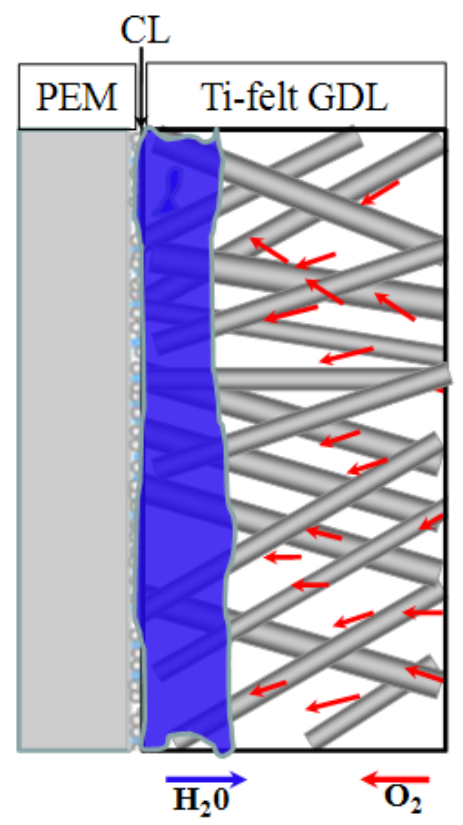

(A) Uniform pore distribution Ti-felt GDL

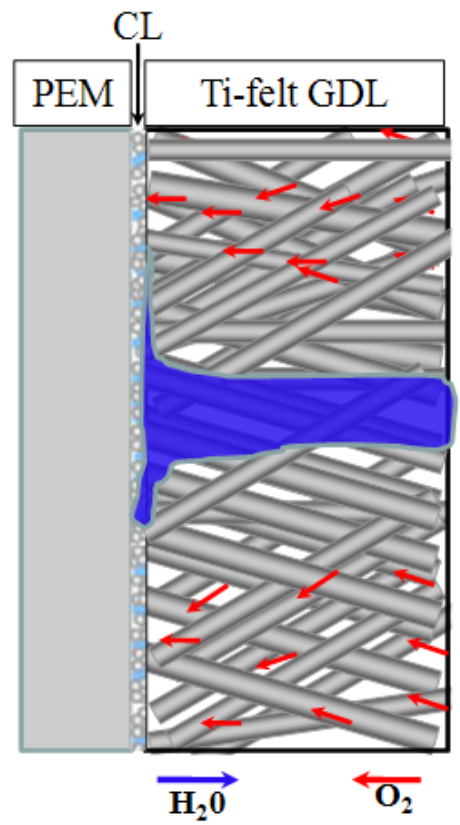

(B) Ununiform pore distribution Ti-felt GDL

Figure 19. Schematic of liquid water and air transport for different Ti-felt GDL substrates (A) with uniform pore distribution structure as in U1 (B) with ununiform pore distribution pore distribution as in $\mathrm{U} 4, \mathrm{U} 5$, and $\mathrm{U} 6$. 
Figure 20

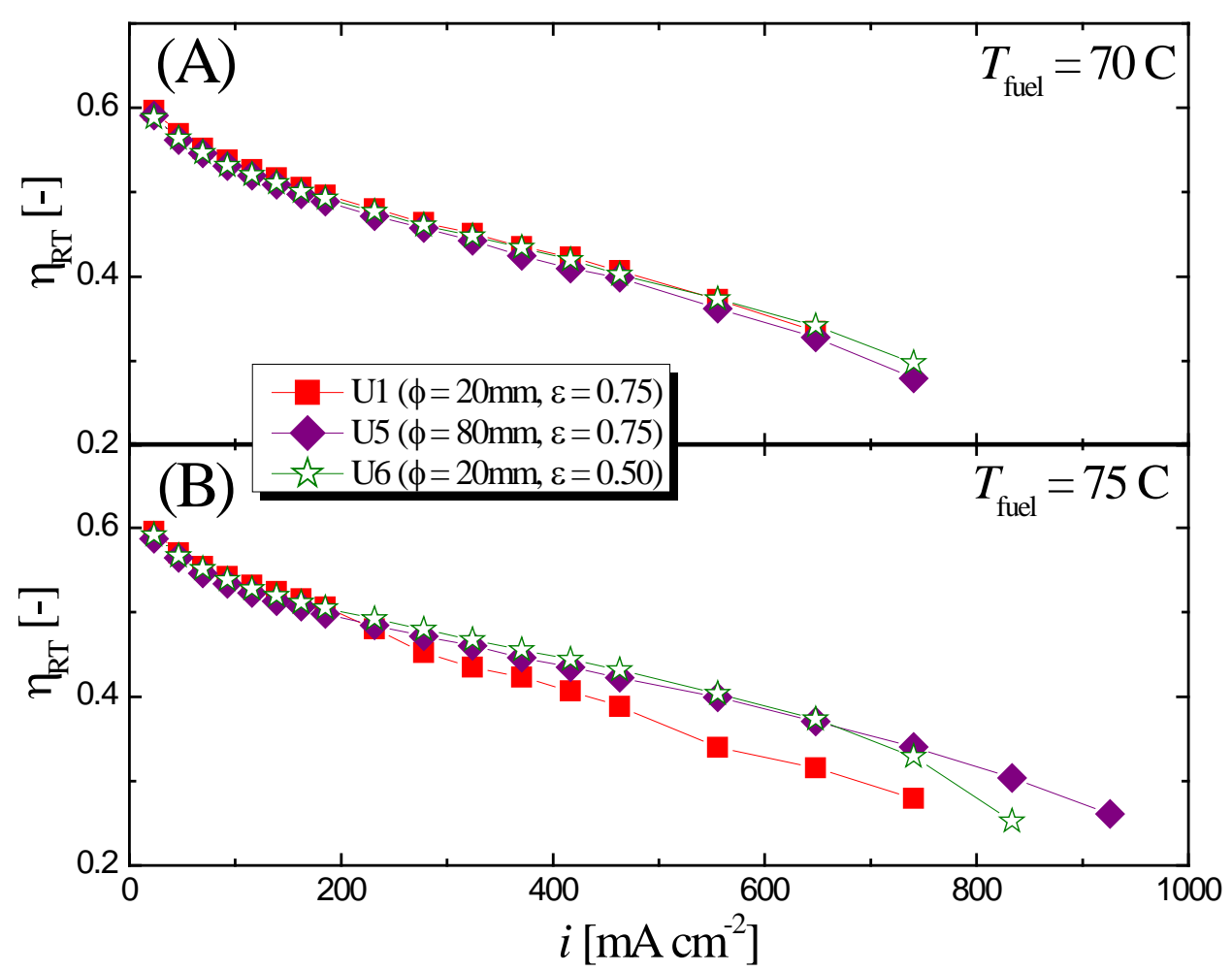

Figure 20. Effect of fiber diameter $(\phi)$ and porosity $(\varepsilon)$ of Ti-felt GDLs on the current density $(i)$ and round-trip efficiency $\left(\eta_{\mathrm{RT}}\right)$ during electrolysis and fuel cell modes for U1, $\mathrm{U} 5$, and U6 cells at humidification temperature $\left(T_{\text {fuel }}\right)$ of (A) 70 and (B) $75^{\circ} \mathrm{C}$. Cell temperature $\left(T_{\text {cell }}\right)$ was $80^{\circ} \mathrm{C}$. 
Table I. GDL properties at the oxygen electrode for the URFC performance test a).

\begin{tabular}{|c|c|c|c|c|c|c|c|}
\hline \multirow[t]{2}{*}{ Cell ${ }^{\text {b) }}$} & $\begin{array}{c}\mathrm{GDL}\left(\mathrm{O}_{2} \text { side }\right) \\
\text { substrate }\end{array}$ & $\begin{array}{l}\text { Fiber diameter } \\
\text { of substrate }(\phi)\end{array}$ & Porosity $(\varepsilon)$ & PTFE loading & $\begin{array}{c}\text { Bubble point } \\
\text { diameter (BPD) }{ }^{\text {c) }}\end{array}$ & $\begin{array}{c}\text { Mean pore } \\
\left.\text { diameter (MPD) }{ }^{\mathrm{c}}\right)\end{array}$ & 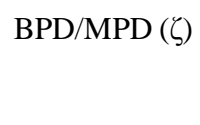 \\
\hline & & {$[\mu \mathrm{m}]$} & & [wt.\% in emulsion] & {$[\mu \mathrm{m}]$} & {$[\mu \mathrm{m}]$} & \\
\hline U1 & Ti-felt & 20 & 0.75 & - & 56.7 & 45.0 & 1.26 \\
\hline U2 & Ti-felt & 20 & 0.75 & $10 \%$ & 45.9 & 36.4 & 1.26 \\
\hline U3 & Ti-felt & 20 & 0.75 & $20 \%$ & - & - & \\
\hline $\mathrm{U} 4$ & Ti-felt & 40 & 0.75 & - & 178.0 & 93.4 & 1.91 \\
\hline U5 & Ti-felt & 80 & 0.75 & - & 511.7 & 207.4 & 2.47 \\
\hline U6 & Ti-felt & 20 & 0.50 & - & 40.9 & 23.3 & 1.76 \\
\hline $\mathrm{F} 1$ & Carbon paper & $10^{\text {d) }}$ & 0.78 & - & 30.1 & 26.4 & 1.14 \\
\hline $\mathrm{F} 2$ & Carbon paper & $10^{\text {d) }}$ & 0.78 & $10 \%$ & - & - & \\
\hline
\end{tabular}

a) Carbon paper GDL coated with PTFE (10wt\% emulsion) is commonly used for the hydrogen-side GDL.

b) "U" indicates a URFC that can be operated as both fuel cell and electrolyzer, and "F" indicates an FC that can be operated only as a fuel cell.

c) Measured with permeability test apparatus using the bubble point technique.

d) Estimated value based on SEM images. 
Table II. Operating conditions of URFC during electrolysis and fuel cell modes.

\begin{tabular}{|c|c|c|}
\hline & Hydrogen electrode & Oxygen electrode \\
\hline Electrolysis operation mode & Cathode & Anode \\
\hline Cell temperature $\left(T_{\text {cell }}\right)$ & \multicolumn{2}{|c|}{$80^{\circ} \mathrm{C}$} \\
\hline Flow rate of circulating water & $50 \mathrm{ml} / \mathrm{min}$ & $50 \mathrm{ml} / \mathrm{min}$ \\
\hline Gas pressure & \multicolumn{2}{|c|}{ Atmospheric } \\
\hline Fuel cell operation mode & Anode & Cathode \\
\hline Cell temperature $\left(T_{\text {cell }}\right)$ & \multicolumn{2}{|c|}{$80^{\circ} \mathrm{C}$} \\
\hline Stoichiometric ratio of gas & 1.43 & 2.50 \\
\hline Gas pressure & \multicolumn{2}{|c|}{ Atmospheric } \\
\hline
\end{tabular}

